International Financial Volatility and Commodity Exports:

Evidence from the Thai Agricultural Sector

Justin B. May

College of William and Mary

College of William and Mary

Department of Economics

Working Paper Number 65

October 2007 
COLLEGE OF WILLIAM AND MARY

DEPARTMENT OF ECONOMICS

WORKING PAPER \#65

October 2007

\title{
International Financial Volatility and Commodity Exports: Evidence from the Thai Agricultural Sector
}

\begin{abstract}
While the demise of many tightly-managed exchange rate regimes has meant that exchange rate volatility has risen for most developing countries in the past few decades, there exists little consensus on the ramifications of that volatility for real sectoral performance. Using production and export data from the Bank of Thailand, this paper measures the effect of real exchange rate volatility on Thai production and export of five key agricultural commodities. I measure volatility as the moving average standard deviation of the daily real value of the baht, the residual of an ARMA $(5,4)$ process of the monthly real value of the baht, the residual of an $\operatorname{ARIMA}(2,1,3)$ process of the daily real value of the baht, and as the conditional time variance of the GARCH(2,1) process of the monthly real value of the baht. I then estimate the effects of real currency fluctuations across the agricultural sectors, controlling for both the level of the real exchange rate and foreign incomes. Point estimates of the effect of real exchange rate volatility on the volume of exports are consistently negative and often statistically significant lending support to a range of theoretical models that predict such an effect. Further, I find no significant relationship between production and lagged values of real exchange rate volatility and the control variables, suggesting that volatility is not an important determinant of agricultural supply. These results are robust to the choice of any of the measures of volatility considered here.
\end{abstract}

JEL Codes: F14, O13, O24

Keywords: Agriculture, Exchange Rate Volatility, Exports, Thailand, Trade

Justin B. May

Department of Economics

College of William and Mary

Williamsburg, VA 23187-8795

jbmay@wm.edu 


\section{INTRODUCTION}

One of the most crucial policy choices facing a developing country is its choice of exchange rate regime. Pegging the exchange rate to that of a major trading partner provides stability and predictability, leading to favorable conditions in which to write long-term international contracts and facilitating international trade - or so the typical story goes, at least. Since a fixed exchange rate system implies an externally determined monetary policy, this type of arrangement can provide a useful nominal anchor and often contributes to disinflation.

The downside of such fixed exchange rate regimes is exactly the same as their upside - their rigidity. Fixing the value of one country's currency to that of another results in a loss of monetary sovereignty. To the extent that shocks to both economies are similar in timing, direction, and magnitude, this loss of monetary sovereignty is relatively inconsequential. However, to the extent that business cycles in the two countries are asymmetric or to the extent that the countries have divergent long run growth rates, imposition of externally determined monetary policy can have disastrous consequences. Moreover, the inability of market forces to change the relative value of the currency eliminates an important means of external adjustment. Finally, fixed exchange rate systems without sufficient reserves invite speculative attacks that often serve to destabilize the economy, especially in the current era of highly mobile financial capital.

Floating exchange rate regimes are not without their own set of risks. Monetary sovereignty, while useful for conducting short-term monetary policy actions and as an automatic remedy for external imbalances, can be risky. Central banks that are insufficiently insulated from the political process, a condition not atypical of developing country central banks, may feel pressure to pursue overly expansionary monetary policy in the run-up to elections or to serve as a lender to the federal government. Volatile exchange rates can make international contracting more difficult and create exchange rate risk that may only be hedged at significant transaction cost, and these effects can dampen incentives for international trade.

The capital account liberalizations undertaken by many developing countries in the last few 
decades have led, in general, to greater volatility of the real exchange rate, and the bout of international contagion experienced during the financial crises of the late 1990s and early 2000s powerfully underscored the potential drawbacks of a system in which rapidly moving capital can cause major exchange rate swings. ${ }^{1}$ Some authors have even advocated a change to the international financial architecture, arguing that the increase in globalization of capital flows has done more harm than good. It is difficult to evaluate the strength of such arguments, however, given the often conflicting answers yielded by previous empirical work estimating the relationship between real exchange rate volatility and real sector performance.

During and following the 1997 Asian financial crisis, Thailand experienced significant volatility of the real exchange rate as speculation forced a transition from a heavily-managed regime to a floating exchange rate. Several periods in Thailand, both pre- and post-crisis, have been characterized by considerable volatility of the real exchange rate. Figure 1 shows the real dollar/baht exchange rate over time. The figure is dominated by two sharp drops in the real value of the baht - one related to the mid-80s devaluation and one related to the 1997 crisis. Economic theory suggests two potentially countervailing effects of exchange rate uncertainty on the volume of trade. If goods are storable and agents are relatively risk-neutral (or risk-loving), then greater volatility may lead to greater exports as exporting agents simply wait for changes in the real exchange rate to create improvements in the terms of trade. On the other hand, if goods are non-storable, if agents are risk-averse, or if hedging risk is costly, then volatility could impair firms' incentive to contract across borders, plausibly leading to lower exports. Hummels (2001) finds that time-tomarket constitutes a considerable barrier to trade, and most firms seem to operate in a manner consistent with at least some degree of risk aversion. For these and other reasons, the second set of arguments, suggesting a negative relationship between exchange volatility and trade, seems to carry more weight.

Theoretical models, however, are mixed in terms of their predictions on the existence of such

\footnotetext{
${ }^{1}$ Currency crises were experienced in Thailand (1997), Korea (1997), Indonesia (1997), Russia (1998), Brazil (1999), and Argentina (2000).
} 
a negative relationship. Ethier (1973) models the decisions of a risk-averse firm in terms of import demand and demand for foreign exchange cover and demonstrates that the volume of trade is unresponsive to exchange rate volatility as long as the firm understands precisely how its revenues depend on future exchange rates. To the extent that firms lack such knowledge, the volume of trade responds negatively to exchange rate uncertainty, though the result is moderated the more speculative is the firm. Sercu (1992) shows that, rather than impeding trade, increased exchange rate uncertainty may create trade by raising the probability that ex post deviations from the law of one price will exceed tariffs and transport costs. Gagnon (1993) constructs a model that emphasizes the negative effect of exchange uncertainty and uses numerical simulations of quarterly data to show that the effect of exchange uncertainty on trade flows would be found to be statistically insignificant even at its upper bound. Bacchetta and van Wincoop (1998) develop a theoretical model to address the impact of fixed versus floating regimes on trade and investment flows. Theirs is a general equilibrium model that admits the possibility of deviations from PPP. They argue that the level of trade is not necessarily higher under a fixed exchange rate regime, but the level of net capital flows is higher under a fixed exchange rate regime with a home bias in bond holdings.

Despite a considerable literature on the subject, empirical studies of the effect of exchange rate volatility on aggregate exports for various countries offer mixed results, at best. In their seminal empirical paper, Hooper and Kohlhagen (1978) build on Ethier's theoretical setup and examine quarterly aggregate and bilateral trade flows between developed countries over the 19651975 period. In the aggregate trade data, they find no significant effect of volatility on either trade volume or prices. In the bilateral data, however, the authors find some relation between exchange volatility and price, though with conflicting sign depending on the country pair. They attribute this conflict to differences in the currency denomination of contracts. DeGrauwe (1987) concentrates on long run variability of the real exchange rate, arguing that long run misalignments in the relative real value of currencies have led to political pressure toward protectionism and that it is this protectionism, rather than the variability itself, that led to a slowdown in the growth of trade during the 1973-1984 period. He notes, however, that while the long run variability of the exchange rate was a significant contributor to the decline in trade growth, other factors - namely 
the worldwide decline of output growth and the slowdown in the pace of trade integration-were quantitatively more important. Cushman (1988) reports generally negative effects of exchange rate risk on U.S. bilateral trade.

More recent empirical work continues to yield little consensus. Koray and Lastrapes (1990) report that the effect of exchange rate volatility on U.S. imports from other developed countries is weak. Asseery and Peel (1991) find that, in the context of an error correction model, exchange rate volatility is, in general, associated with higher values of an export volume index for five developed countries. On the other hand, Caporale and Doroodian (1994) use a GARCH specification to show that exchange volatility has had a negative and statistically significant effect on trade flows between the U.S. and Canada. Chowdhury (1993) employs an error correction setup and, in contrast to Asseery and Peel, finds a negative effect of volatility on trade flows of G-7 countries. Baum, et al. (2003) is one of the few prior studies to examine daily exchange rate data in calculating measures of volatility. They examine monthly bilateral trade data for 13 developed countries over the 19801998 period and find, on average, a positive effect of exchange rate volatility on real exports. McKenzie (1999) provides a comprehensive survey of the state of the empirical literature and notes the continued disagreement across studies of the effect of exchange rate volatility on trade flows. He (like others more recently) postulates that studies of aggregate effects may obfuscate the relationship and that the most meaningful results may be obtained by careful examination of specific export markets over short time horizons.

Historically, agriculture has been central to the Thai economy. Even today, after decades of relatively rapid development, agriculture represents more than 10 percent of both GDP and exports. Preliminary evidence for Thailand suggests that while aggregate exports are relatively unresponsive to exchange rate volatility, specific agricultural industries may be differentially affected. However, early studies were hampered by a paucity of data for the post-crisis period (Langley, et al. 2000). Agricultural exports are also convenient to study because they are almost completely commoditized and because reliable monthly data exist on the weight of agricultural export shipments, meaning that product differentiation is virtually nonexistent and that export volume should be very precisely 
measured. Commodity exporters choose only quantities - rather than quality, brand, or product mix - thus providing an ideal group from which to discern the export volume effects of exchange rate volatility. This paper's intent is to deepen and extend the previous work evaluating the effect of real exchange rate volatility on agriculture. It is my hope that by focusing on a narrow group of industries, using monthly exports and production data, and using several competing measures of exchange volatility (including daily measures) that the relationship between volatility and exports may be brought into sharper focus.

Using industry level production and export data from the Bank of Thailand, this paper measures the differential effects of exchange rate volatility on monthly Thai production and export of five key agricultural commodities. I measure volatility as the moving average standard deviation of the daily real dollar/baht exchange rate, the residual of an $\operatorname{ARMA}(5,4)$ process of the monthly real bilateral exchange rate, the residual of an $\operatorname{ARIMA}(2,1,3)$ process of the daily real bilateral exchange rate, and as the conditional time variance of the generalized autoregressive conditionally heteroskedastic (GARCH) process of the monthly real dollar/baht exchange rate (Bollerslev 1986). In the GARCH estimation, the monthly real exchange rate is first modeled as an ARMA $(5,4)$ model. Then, a GARCH $(2,1)$ model is fit to the residuals of the ARMA process. The predicted values from the GARCH estimation then constitute a measure of the conditional time variance of the monthly real exchange rate and this predicted measure is then used as the measure of volatility in linear regressions explaining sectoral exports.

Each of these regressions also includes controls for foreign income and the level of the real exchange rate. In this way, I am able to measure only the change in industry exports attributable to real exchange rate volatility. Point estimates using each of the four measures of volatility support the hypothesis of a negative relationship between the volatility of the real exchange rate and the volume of exports, and the estimates are often statistically significant. This stands in contrast to most earlier work, which generally fails to discern such a relationship. By quantifying the industry level consequences of real exchange rate volatility, this paper arms policymakers with greater information on the tradeoffs inherent in the choice of an exchange rate regime. 
The remainder of the paper is organized as follows: Section 2 lays out a model in which the volatility of the exchange rate affects the decisions of a hypothetical agricultural exporter. Section 3 describes the data employed and the estimation strategy. Section 4 examines the evidence based on several specifications of the empirical model. Section 5 offers conclusions and provides directions for useful future work.

\section{The Model}

I model the decision making process of a hypothetical risk averse Thai exporter of a refined commodity in industry $i$. The exporter purchases a domestically sourced raw agricultural commodity, and then produces a refined product for sale on both domestic and world markets with a one-period lag. I model world demand for the commodity as infinitely elastic at price $P_{w, t}^{i}$. This exporter also refines for the domestic market, though in the domestic market the producer faces a downward sloping demand curve for its output and an upward sloping supply curve for the raw material. The exporter must decide at time $t-1$ how much of the refined commodity to purchase $(Q)$ and the proportion of foreign receipts to be hedged through forward contracts $(\gamma)$. Then, at time $t$, the producer faces a decision over the proportion of the refined commodity to sell in the domestic market $(\alpha)$ given the prior choices of $Q$ and $\gamma$.

The ex post value of the firm's refining and exporting activities are thus given by

$$
V(Q, \alpha, \gamma)=\alpha Q P_{d, t}^{i}+(1-\alpha) Q P_{w, t}^{i}\left[\gamma e^{f}+(1-\gamma) e\right]-C(Q) \text { with } 0<\alpha<1,
$$

where $P_{d, t}^{i}$ represents the domestic price of industry $i$ 's output at time $t$ denominated in baht, $P_{w, t}^{i}$ represents the world price of industry $i$ 's output at time $t$ denominated in dollars, $e_{t-1}^{f}$ represents the one period forward baht/dollar rate available in period $t-1, e_{t}$ represents the spot baht/dollar exchange rate that prevails at time $t$, and $C(Q)$ represents the cost of purchasing and refining enough of the raw commodity to produce $\mathrm{Q}$ units of the refined commodity. That is, $V$ represents the baht-denominated producer surplus of the firm. ${ }^{2}$

\footnotetext{
${ }^{2}$ It is worthwhile to note that this specification of the firm's value function abstracts from any intertemporal
} 
However, several of these quantities are not known to the firm at time $t-1$. If we let $E[\cdot]$ represent the standard expectations operator, we can write a time $t$ expected value function for the exporter given knowledge at time $t-1$

$$
E_{t-1}\left[V_{t}(Q, \alpha, \gamma)\right]=\alpha Q E_{t-1}\left[P_{d, t}^{i}\right]+(1-\alpha) Q E_{t-1}\left[P_{w, t}^{i}\right]\left[\gamma e_{t-1}^{f}+(1-\gamma) E_{t-1}\left[e_{t}\right]\right]-C(Q)
$$

Because the exporter is large by domestic standards, it is reasonable to assume that it faces increasing costs. Thus, it is assumed that

$$
C^{\prime}>0
$$

and

$$
C^{\prime \prime}>0
$$

Because of the risk-aversion of the exporter, its principals seek to maximize not $E[V]$, but $E[U(V)]$ where $U$ represents a standard vonNeumann-Morgenstern utility function and

$$
\begin{gathered}
U^{\prime}>0, \\
U^{\prime \prime}<0,
\end{gathered}
$$

and

$$
U^{\prime \prime \prime}<0
$$

The strict concavity of the utility function implies that the firm will always strictly prefer a certain value of $V$ to a fair gamble leading to the same expected value of $V$, while negativity of $U^{\prime \prime \prime}$ ensures that the firm necessarily changes its optimizing behavior in response to this uncertainty.

Maximization necessarily occurs in two stages. First, at time $t-1$, the firm must choose a level of $Q$ and a proportion of foreign exchange cover to obtain. I assume that the firm incurs some

decision. In theory, a firm free from credit constraints could hold its output indefinitely in hopes of an improvement in the terms of trade. In practice, firms often face credit constraints and recent empirical work suggests that time between production and consumption constitutes a meaningful trade barrier. For these reasons and for ease of exposition, intertemporal considerations of longer than one period are omitted here. 
cost of hedging. The expression $e_{t-1}^{f}$ represents the exchange rate available net of that cost, and therefore it is safe to assume that

$$
e_{t-1}^{f}<E_{t-1}\left[e_{t}\right]
$$

Although hedging costs, it is assumed that the firm is sufficiently risk-averse and the cost is sufficiently small that the firm still optimally hedges some amount. Thus, we have $0<\gamma<1$. It is important even at this early stage of the maximization that the firm have some expectations about $\alpha$. This is necessary because the firm must determine not only the proportion of export receipts to hedge through forward contracts but also their dollar value. I assume that in the early stage of the maximization the firm maintains an $\alpha$ equal to that which it chose in the latter stage of the previous period's maximization.

Considering the firm's first order condition for the maximization of expected utility with respect to the choice of $Q$ yields the following equality

$$
\begin{aligned}
& \frac{\partial E_{t-1}[U]}{\partial Q}=\left[\alpha \frac{\partial E_{t-1}\left[P_{d, t}^{i}\right]}{\partial Q}+(1-\alpha) E_{t-1}\left[P_{w, t}^{i}\right]\left[\alpha e_{t-1}^{f}+(1-\alpha) E_{t-1}\left[e_{t}\right]\right]-C^{\prime}(Q)\right] * \\
& E_{t-1}\left[U^{\prime}\right]=0 \text {. }
\end{aligned}
$$

That is, the firm purchases raw materials and produces until its expected disutility due to per-unit costs rises to equal the expected utility due to per-unit remuneration. This is nothing more than a simple marginal revenue equal to marginal cost condition for a risk-averse firm.

Considering the firm's first order condition for the maximization of expected utility with respect to the choice of $\gamma$ yields the following equality

$$
\frac{\partial E_{t-1}[U]}{\partial \gamma}=\left[(1-\alpha) E_{t-1}\left[P_{w, t}^{i}\right] Q e_{t-1}^{f}-(1-\alpha) E_{t-1}\left[P_{w, t}^{i}\right] Q E_{t-1}\left[e_{t}\right]\right] E_{t-1}\left[U^{\prime}\right]=0
$$

If we let $f\left(e_{t}\right)$ represent the probability density function of the random variable $e_{t}$, we can rewrite this condition as

$$
\left[(1-\alpha) E_{t-1}\left[P_{w, t}^{i}\right] Q e_{t-1}^{f}\right] E_{t-1}\left[U^{\prime}\right]=\int_{0}^{\infty}(1-\alpha) E_{t-1}\left[P_{w, t}^{i}\right] Q E_{t-1}\left[U^{\prime}\right] d f
$$


This implies that the firm will hedge until the expected marginal utility from hedging is just equal to the expected marginal utility from the unhedged receipts. Note, too, that a mean preserving spread of $e_{t}$ (i.e., higher volatility) combined with the assumed properties of the utility function will lead to lower marginal utility from the firm's unhedged export sales. This implies that the firm should react to a perceived increase in exchange rate volatility by increasing the proportion of its foreign receipts that it optimally chooses to hedge. Moreover, the firm will be willing to hedge even at larger gaps between $e_{t-1}^{f}$ and $E_{t-1}\left[e_{t}\right]$. The firm's certainty premium will have increased.

Finally, the firm gets to decide the proportion of its output to supply to the domestic market. This decision takes place at time $t$, after the realization of the random variables $P_{w, t}^{i}$ and $e_{t}$, and thus, the firm is free to deviate from its initial plans. Maximization of utility with respect to $\alpha$ yields

$$
\frac{\partial U}{\partial \alpha}=\left[\frac{\partial P_{d, t}}{\partial \alpha} Q-P_{w, t} Q\left[\gamma e_{t-1}^{f}+(1-\gamma) e_{t}\right]\right]\left[U^{\prime}\right]=0 .
$$

That is, the firm will choose $\alpha$ such that its marginal revenue is equalized across the domestic and foreign markets. In particular, if the realization of $e_{t}$ is lower (higher) than expected, the firm will sell more (less) to the domestic market and less (more) to foreign markets until marginal revenues are equalized.

Let us now return to the issue of exchange rate volatility. As exchange rate volatility increases, the firm optimally chooses to hedge a larger percentage of its foreign receipts. This increased hedging drives down the expected return from foreign sales (recall that hedging is not costless) and causes the firm optimally to choose to sell a larger fraction of its output domestically. Thus, the model predicts that increases in exchange rate volatility should be associated with lower volumes of exports. ${ }^{3}$

\footnotetext{
${ }^{3}$ Note that these effects occur without the assumption that the certainty premium increases in a more volatile exchange rate environment. Adding this feature would bolster the predicted effect.
} 


\section{Data and Estimation Strategy}

Daily exchange rate data come from the Federal Reserve Bank of New York and cover the 1981-2006 period. Monthly data on Thai production, exports, and prices over the same period come from the Bank of Thailand's Quarterly Bulletin. Macroeconomic data for the U.S. come from the Federal Reserve Bank of St. Louis' Federal Reserve Economic Data (FRED) Database. Similar data for other principal Thai trading partners are drawn from the International Monetary Fund's International Financial Statistics database.

Exchange uncertainty is modeled in four distinct ways. The first and most elementary way is to calculate the trailing moving average standard deviation of the real exchange rate measured as

$$
\operatorname{Var}_{t}=\left[\frac{1}{d} * \sum_{i=1}^{d}\left(z_{t+1-i}-z_{t-i}\right)^{2}\right]^{\frac{1}{2}}
$$

where $z$ represents the log relative price of foreign consumer goods in terms of Thai consumer goods and $d$ represents the order of the moving average. Because only historical exchange rates are known at any point in time, a trailing rather than centered moving average is employed. Other authors, such as Kenen and Rodrik (1986), Cushman (1988), and Koray and Lastrapes (1989), have used centered moving averages instead, but this technique fails to capture the trading firm's fundamental inability to predict future volatility. Because the average trading month in the data contains 20.6 observations of the exchange rate, I use values of 21,62 , and 103 for $d$ to create what are essentially one-, three-, and five-month moving average values. The average of these trailing moving average values in any calendar month becomes that month's observation in the regressions that follow.

The second method used to estimate the volatility of the real exchange rate is to fit an autoregressive integrated moving average (ARIMA) process to the monthly real exchange rate data and to interpret the residual from that process as exchange rate volatility. Tables 1,2 , and 3 show the Akaike Information Criterion for various ARIMA specifications. The tables are organized by the degree of differencing, with an asterisk denoting the model choice for each difference specification. Since the Akaike Information Criterion is decreasing in the adjusted log likelihood of the model, 
lower values of the Criterion indicate a better fit (after a penalty proportional to the number of parameters estimated). Overall, the best fit was achieved with an $\operatorname{ARMA}(5,4)$ model, and the results of this estimation are reported in Table 4.

The third technique for measuring real exchange rate volatility is to fit an ARIMA model to the daily data. Again the choice of an appropriate specification is made based on the Akaike Information Criterion. Tables 5, 6, and 7 report the values of the Criterion for various formulations of the model. In fitting the model to the daily data, an $\operatorname{ARIMA}(2,1,3)$ is the most preferred specification. Table 8 reports the parameter estimates for this model. The daily values of these residuals are then aggregated into 21-, 62-, and 103-day trailing moving averages similar to those employed in calculating the sample standard deviation above.

The final technique employed to estimate the volatility of the real exchange rate takes specific account of the serial autocorrelation of volatility. The estimation proceeds in two steps. First, the most preferred $\operatorname{ARMA}(5,4)$ model is fit to the monthly bilateral real exchange rate data. Then, a $\operatorname{GARCH}(2,1)$ model is fit to the residuals of the ARMA estimation. As before, the GARCH(2,1) model is chosen based on the Akaike Information Criterion. The fitted values of the GARCH $(2,1)$ estimation then constitute the conditional time variance of the real exchange rate series and are the final measure of exchange rate volatility to be considered here. Figure 2 presents the results of each of the four measures of volatility. The two series constructed from daily data are presented as 103-day moving averages. All four series seem to have the same general shape, though pairwise deviations are fairly large at some dates.

I then include each of the foregoing measures of volatility as a regressor in OLS regressions of the monthly volume of agricultural exports. Export volume for each of five heavily traded agricultural commodities (maize, rice, rubber, sugar, and tapioca) is regressed on the measure of volatility of the real exchange rate, the level of the real exchange rate, and industrial production of the U.S., Japan, Hong Kong, and the Euro Area. ${ }^{4}$ Monthly industrial production serves as a useful

\footnotetext{
${ }^{4}$ Due to the short time series of industrial production data available for the euro area, it is found to be statistically
} 
proxy for foreign income and is often a significant determinant of export volumes. OLS regressions take the following form

$$
X_{t}^{i}=\beta_{0}+\beta_{1} V A R_{t}+\beta_{2} R E R_{t}+\beta_{3} I P_{u s, t}+\beta_{4} I P_{j p, t}+\beta_{5} I P_{h k, t}+\beta_{6} I P_{e a, t},
$$

where $X_{t}^{i}$ represents the volume (in thousands of metric tons) of exports a given Thai agricultural product, $V A R_{t}$ represents the measure of volatility of the real dollar/baht exchange rate, $R E R$ represents the level of the real dollar/baht exchange rate, and the IP terms represent industrial production of major Thai trading partners. The parameter of interest is $\hat{\beta}_{1}$. A similar technique is employed to estimate the effect of exchange rate volatility on production. However, because production of the raw agricultural commodity occurs with a four to eight month lag between planting and harvest, I regress production on lags of each of the above variables. Again the variables of interest in this instance are the coefficients on lags of the volatility term.

\section{Results}

Table 9 reports the results of regressing commodity exports on the 103-day moving average standard deviation of the real exchange rate. ${ }^{5}$ For each of the six cases reported, the point estimate of the coefficient on this measure of volatility is negative, as predicted by the model of a risk-averse refiner/exporter. In the cases of maize and sugar, however, the coefficient is not significantly different from zero. Interpreting the magnitude of the coefficient presents some difficulty, but it is useful to bear in mind that the standard deviation of the measure of volatility employed here is 4.61e-5. Thus, a one standard deviation increase in the volatility measure translates to a decrease in maize exports of 4,249 metric tons per month, in rice exports of 15,116 metric tons per month, in rubber exports of 7,242 metric tons per month, in sugar exports of 8,957 metric tons per month,

\footnotetext{
insignificant in every specification. Thus, it is not reported in any of the regression tables.

${ }^{5}$ In each case in which daily data are aggregated to construct a volatility measure, the five-month measure yields a better fit than other time horizons. This suggests that refiner/exporters have a relatively long memory of volatility or that their exporting behavior changes only with significant inertia.
} 
in tapioca exports of 21,547 metric tons per month, and in the value of total Thai exports of $\$ 127$ million per month. The overall goodness of fit of the model as measured by $\bar{R}^{2}$ ranged from a low of around 0.14 in the case of Thai sugar exports to a high of 0.92 in the case of overall Thai exports.

The industrial production terms used as proxies for foreign incomes are frequently significant, though the signs of the coefficients are sometimes puzzling. For example, if we examine the case of U.S. industrial production, we might expect positive coefficients on rice, rubber, and sugar, since the U.S. is a net importer of those commodities. Similarly, the negative coefficient on $I P_{u s}$ for maize might be explained by some correlation between maize production and overall U.S. output combined with the fact that the U.S. is a major exporter of maize. No similar explanation seems to be plausible for the negative coefficient on $I P_{u s}$ in the regression explaining Thai tapioca exports. Moreover, it is difficult to understand why the coefficient on the level of the real exchange rate should be negative for maize, rice, and tapioca, unless foreign demand, rather than domestic supply were the true determinant of Thai exports of these commodities.

The results of regressing Thai exports on the residual of an ARMA(5,4) process of the monthly real exchange rate appear in Table 10. The outcomes are broadly similar to those achieved using the 103-day moving average standard deviation of the real exchange rate as the measure of variance. In this case, however, the coefficient on volatility in the regression explaining maize exports is an imprecisely estimated positive number rather than an imprecisely estimated negative number. Point estimates of the volatility coefficient for the other commodities and for total exports remain negative, though only in the case of tapioca is the coefficient statistically significant. In this case, however, the predicted response to a one standard deviation change in real exchange rate volatility are much larger. The coefficients predict that a one standard deviation increase in volatility would lead to an increase in maize exports of 5,717 metric tons per month and decreases in exports of rice of 675 metric tons per month, in exports of rubber of 1,682 metric tons per month, in exports of sugar of 10,266 metric tons per month, in exports of tapioca of 31,315 metric tons per month. The value of total exports would be reduced by $\$ 85$ million per month. Again, the puzzling patterns of coefficients on industrial production and the level of the real exchange rate emerge. As before, 
values of $\bar{R}^{2}$ range from a low of around 0.14 for sugar to a high of around 0.91 for total exports.

Table 11 lists the coefficient estimates from regressions of commodity exports and total exports on the 103-day trailing moving average of the residual from the $\operatorname{ARIMA}(2,1,3)$ process of the daily real exchange rate. As with the regressions of exports on the moving average standard deviation of the daily real exchange rate, a moving average of 103-day order was found to yield the best fit. In fact, the results overall are very similar between these two specifications. As before, point estimates of each of the coefficients on the variance term are negative, though they are imprecisely estimated in the cases of maize and sugar. Using the coefficients obtained here, a one standard deviation increase in the volatility of the real exchange rate leads to decreases in maize exports of 4,199 metric tons per month, in rice exports of 15,042 metric tons per month, in rubber exports of 7,325 metric tons per month, in sugar exports of 8,911 metric tons per month, in tapioca exports of 21,643 metric tons per month, and in the value of total Thai exports of $\$ 126$ million per month. Values of $\bar{R}^{2}$ are nearly identical to those generated by the previous specifications.

Table 12 displays the coefficients obtained by regressing the volume of monthly commodity exports on the predicted value of the $\operatorname{GARCH}(2,1)$ process of the residual of the $\operatorname{ARMA}(5,4)$ estimated on monthly data as well as controls. Because periods of high volatility tend to be clustered, several authors have argued that it is the conditional rather than the unconditional volatility of the real exchange rate series that should determine export volumes. Employing the GARCH technique provides a consistent estimate of this conditional volatility. As in the regression using the $\operatorname{ARMA}(5,4)$ residual, coefficients on the volatility term are generally imprecisely estimated, with the exception of the volume of tapioca exports. The predicted effects of a one standard deviation increase in volatility of the real exchange rate are to increase monthly maize exports by 4,209 metric tons per month and to decrease rice exports by 3,938 metric tons per month, rubber exports by 2,162 metric tons per month, sugar exports by 10,408 metric tons per month, tapioca exports by 26,659 metric tons per month, and the value of total Thai exports by $\$ 72$ million per month. As in each of the foregoing regressions, puzzling differences in the sign on the coefficients on industrial production and the level of the real exchange rate persist. Table 13 summarizes the predicted effects 
of a one standard deviation increase in volatility across commodities and volatility measures. In 18 of the 20 specifications estimated here, volatility of the real exchange rate appears to be negatively related to exports. In 10 of those 18 regressions, the relationship is estimated precisely enough to yield statistical significance.

An alternate explanation for this relationship might be that it is production, rather than the firm's export decision, which is influenced by exchange volatility. That is, it might be that the producers of the raw commodity, rather than the refiner/exporters, choose to produce less in times of high exchange rate volatility. Lowered production, in turn, could plausibly lead to lower levels of exports. Fortunately, detailed monthly Thai production data exist for four of the five agricultural commodities considered above and allow a test of this hypothesis. Because (apart from rubber) planting decisions must be made approximately four to eight months before harvest, in the regressions that follow I consider the effect of lags of the independent variables on agricultural production.

Table 14 reports the coefficient estimates from regressions of agricultural production on lagged values of the 103-day trailing moving average standard deviation of the real exchange rate and the control variables. At least one lag of this volatility measure attains statistical significance for each commodity considered, but the signs often conflict. In fact, of the ten coefficient estimates that are significant (or near-significant) they are evenly divided between positive and negative. Overall, the regressions explain a large fraction of the observed variation in production, with values of $\bar{R}^{2}$ ranging from 0.41 in the case of sugar to 0.73 in the case of maize.

Table 15 shows similar results substituting as the measure of volatility the residual from fitting an ARMA $(5,4)$ model to the real exchange rate. Again, there seems to be little support for the hypothesis that exchange volatility dampens production. Of the 11 estimated coefficients on lagged volatility at or near statistical significance, only four are negative. As in the previous specification, the regressions succeed in explaining a considerable fraction of the overall variation in agricultural production.

Table 16 displays estimated coefficients from regression of agricultural commodity production 
on the residual from the $\operatorname{ARIMA}(2,1,3)$ process of the daily real exchange rate. As with the moving average standard deviation measure of volatility - the other based on daily data - coefficients on the volatility term are equally split between positive and negative. Measures of the goodness of fit of the model are nearly identical to those achieved by the moving average standard deviation measure.

Finally, Table 17 presents the results when the residual of a $\operatorname{GARCH}(2,1)$ process fit to the $\operatorname{ARMA}(5,4)$ process of the monthly real exchange rate represents the volatility measure. Again, the coefficient estimates reject the hypothesis of a negative relationship between volatility and production, with point estimates of seven of ten coefficients on the volatility term taking positive values. As in earlier regressions, the statistical model explains between 40 and 70 percent of the observed variation in production of the four commodities over the 1981-2006 period.

The preponderance of the statistical evidence presented above suggests that volatility of the real exchange rate - however it is measured-reduces firms' incentive to export as predicted by the model. There appears to be little evidence that this reduction in exports comes as a result of an overall decline in supply, as regressions of production on lagged measures of volatility lead more frequently to positive rather than negative coefficient estimates.

\section{Conclusions and Directions for Further Research}

The theoretical portion of this paper demonstrates that, in a world populated by risk-averse commodity refiner/exporters, we should expect volatility of the real exchange rate to diminish export volume. The overwhelming majority of the statistical evidence considered here supports this central implication of the model. Each of four measures of exchange rate volatility is found to diminish the observed export volume of both the agricultural commodities considered here as well as the value of total exports over the 1981-2006 period, and the effect often attains statistical significance. No such negative relationship is found between lagged values of real exchange rate volatility and volume of production, implying that the decrease in exports comes from a refiner's 
choice between selling to the domestic versus the world market and is not simply a consequence of a smaller domestic supply of the commodity. From a policy standpoint this suggests that exporters, as opposed to firms serving only the domestic market, may be differentially negatively affected by policies that induce greater volatility of the real exchange rate.

In contrast to most previous studies, this paper focuses on commodity exports and short timehorizon measurements of volatility. Working with long time-series of data and focusing on short run measures of volatility allows for more precise statistical inference. Choosing a pure volume measure of production and export of undifferentiated products precludes questions about other dimensions of firms' potential response to volatility. That the results found here are robust to any of four measures of real exchange rate volatility suggests that the hypothesized effect does indeed affect firm behavior. Replication of this study for other countries or using industry level exports for manufactures or services would be useful extensions of the work presented here. 


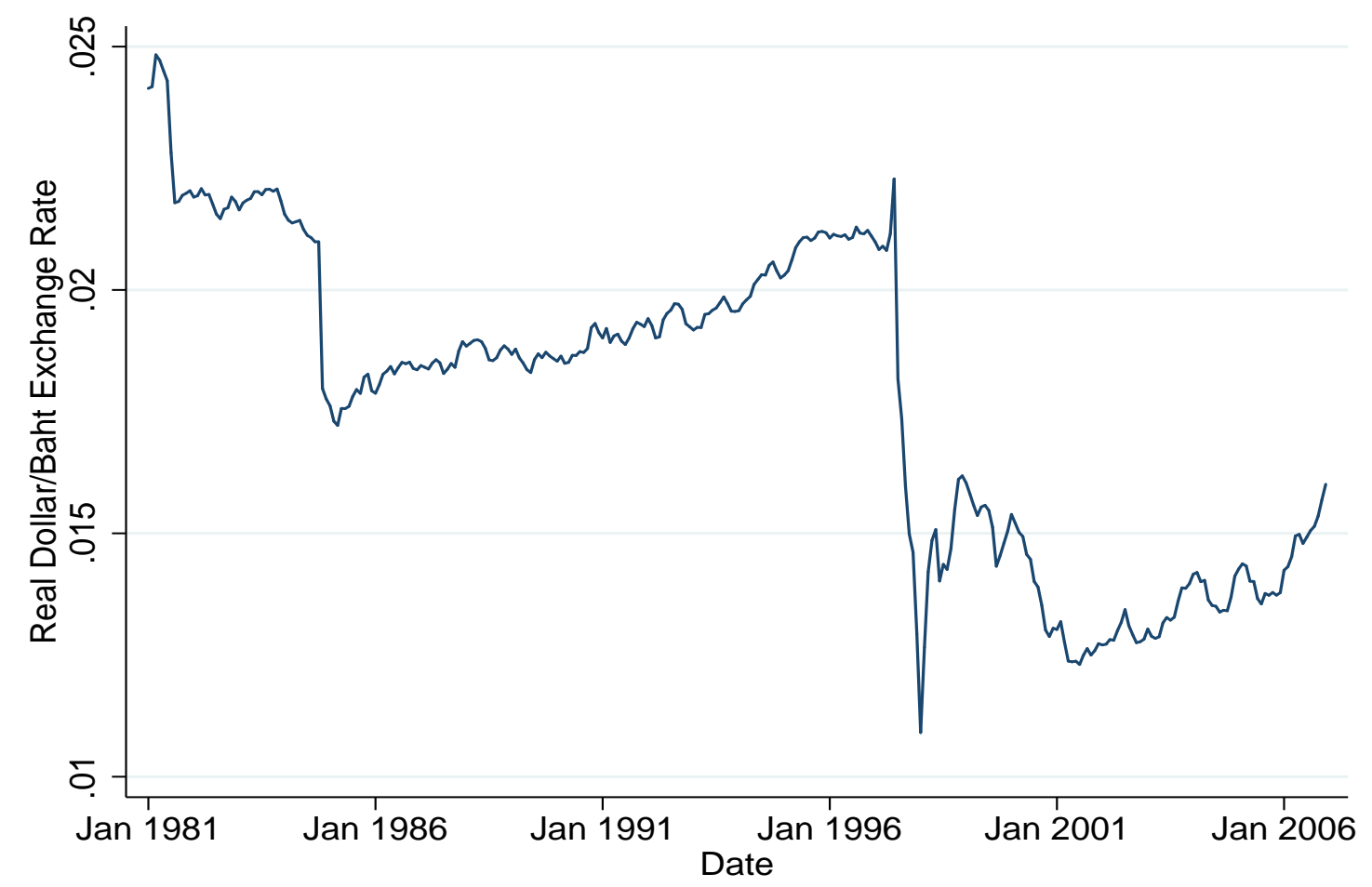

Fig. 1.- Real USD/THB Exchange Rate (CPI) 1981-2006 


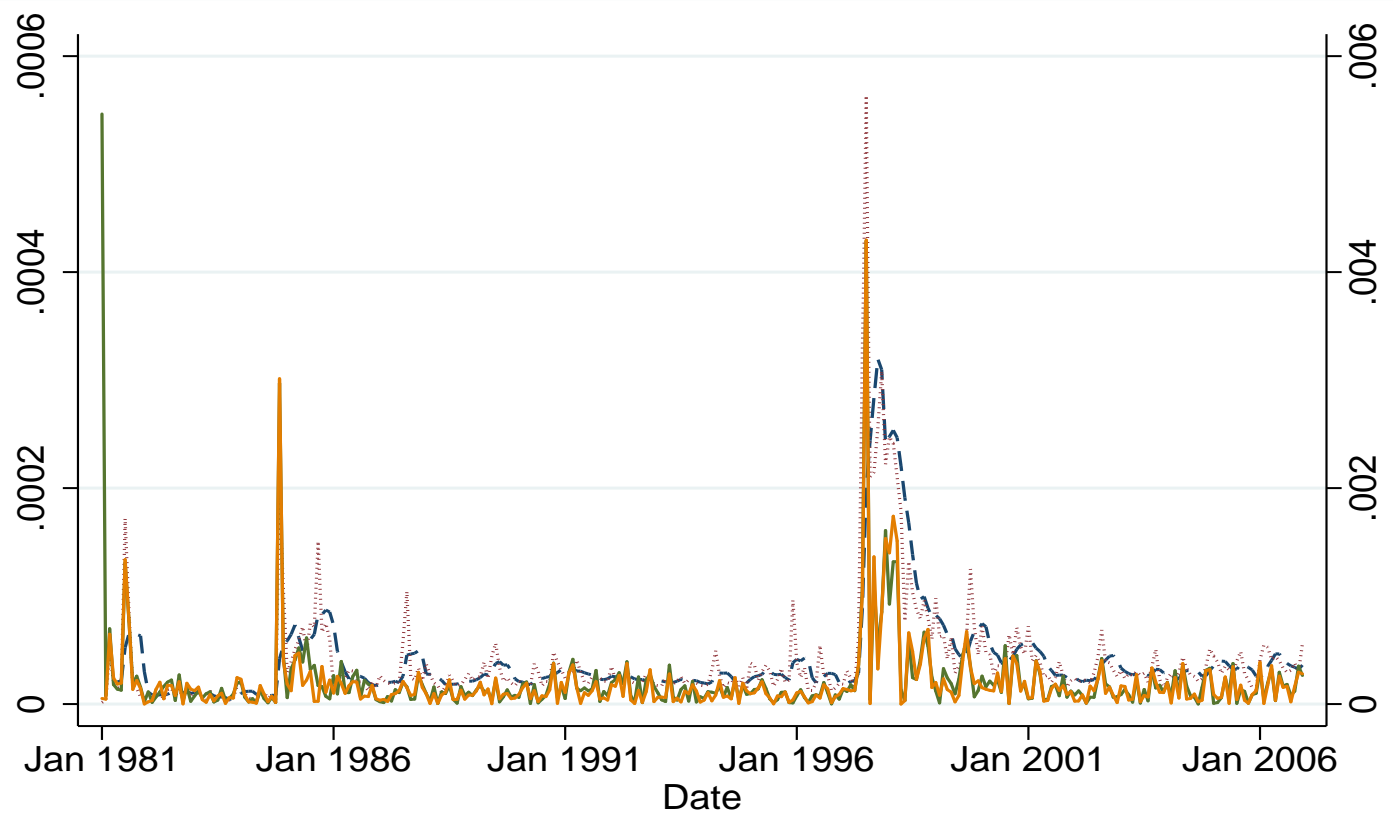

$$
\begin{aligned}
& \text { - - - - 103-Day MA Std. Dev. _ …............... Daily ARIMA(2,1,3) Resid. } \\
& \text { ARMA }(5,4) \text { Resid. (Right Axis) } \quad \text { GARCH(2,1) Fitted (Right Axis) }
\end{aligned}
$$

Fig. 2.- Measures of Volatility of the Real USD/THB Exchange Rate 1981-2006 
Table 1. Akaike Information Criterion for Various $\operatorname{ARIMA}(p, 0, q)$ Specifications of the Monthly Real Exchange Rate

\begin{tabular}{llllcccc}
\hline \hline & \multicolumn{1}{c}{ MA Terms } & & \\
0 & 1 & 2 & 3 & 4 & 5 & 6 \\
\hline
\end{tabular}

\begin{tabular}{lrrrrrrr} 
AR Terms & & & & & & \\
0 &.. & -3076.35 & -3352.97 & -3506.86 & -3661.07 & -3689.89 & -3747.90 \\
1 & -3936.12 & -3945.98 & -3944.54 & -3944.11 & -3945.11 & -3944.47 & -3952.60 \\
2 & -3946.81 & -3945.10 & -3943.22 & -3943.05 & -3943.38 & -3944.21 & -3953.92 \\
3 & -3945.02 & -3943.04 & -3947.56 & -3953.19 & -3952.25 & -3951.29 & -3954.71 \\
4 & -3943.47 & -3942.61 & -3947.65 & -3952.49 & -3950.51 & -3950.14 & -3953.09 \\
5 & -3943.10 & -3942.03 & -3950.90 & -3943.78 & $-3957.59^{*}$ & -3951.41 & -3954.05 \\
6 & -3945.10 & -3943.42 & -3952.89 & -3951.04 & -3949.48 & -3954.83 & -3952.71 \\
\hline
\end{tabular}

Table 2. Akaike Information Criterion for Various ARIMA(p,1,q) Specifications of the Monthly Real Exchange Rate

\begin{tabular}{lccccccc}
\hline \hline & \multicolumn{7}{c}{ MA Terms } \\
\multicolumn{10}{c}{0} & 1 & 2 & 3 & 4 & 5 & 6 \\
\hline & & & & & & & \\
\multicolumn{1}{c}{ AR Terms } & & & & & & & \\
0 & -3929.95 & -3939.04 & -3937.39 & -3936.57 & -3938.18 & -3937.10 & -3943.78 \\
1 & -3939.59 & -3937.69 & -3935.72 & -3935.50 & -3936.39 & -3936.31 & -3945.41 \\
2 & -3937.67 & -3935.70 & -3940.84 & -3945.82 & -3945.18 & -3943.91 & -3946.48 \\
3 & -3935.90 & -3934.99 & -3939.99 & -3945.35 & -3943.40 & -3942.33 & -3944.88 \\
4 & -3936.03 & -3934.92 & -3943.87 & -3943.45 & -3943.99 & -3943.44 & -3946.28 \\
5 & -3937.33 & -3935.54 & -3945.11 & -3943.15 & -3941.57 & -3947.24 & -3945.32 \\
6 & -3936.40 & -3939.08 & -3943.19 & -3942.42 & -3947.26 & -3945.32 & $-3948.40 *$ \\
\hline
\end{tabular}


Table 3. Akaike Information Criterion for Various $\operatorname{ARIMA}(\mathrm{p}, 2, \mathrm{q})$ Specifications of the Monthly Real Exchange Rate

\begin{tabular}{|c|c|c|c|c|c|c|c|}
\hline & \multicolumn{7}{|c|}{ MA Terms } \\
\hline & 0 & 1 & 2 & 3 & 4 & 5 & 6 \\
\hline \multicolumn{8}{|c|}{ AR Terms } \\
\hline 0 & -3767.84 & -3911.65 & -3920.77 & -3917.14 & -3918.35 & -3917.89 & -3916.83 \\
\hline 1 & -3824.29 & -3921.34 & -3917.45 & -3915.49 & -3915.28 & -3918.10 & -3917.64 \\
\hline 2 & -3851.53 & -3919.43 & -3915.61 & -3914.13 & -3927.59 & -3924.92 & -3923.67 \\
\hline 3 & -3855.98 & -3915.68 & -3914.77 & -3919.77 & -3927.09 & -3923.14 & -3924.11 \\
\hline 4 & -3879.25 & -3917.75 & -3913.02 & -3923.61 & -3923.19 & -3921.18 & -3928.56 \\
\hline 5 & -3888.62 & -3917.13 & -3915.37 & -3926.88 & -3922.93 & -3921.34 & -3929.02 \\
\hline 6 & -3888.21 & -3887.61 & -3918.99 & -3920.89 & -3922.22 & $-3929.02^{*}$ & -3925.09 \\
\hline
\end{tabular}

Table 4. ARIMA(5,0,4) Specification for Monthly Real Exchange Rate

\begin{tabular}{|c|c|c|c|c|c|c|}
\hline Variable & Coeff. & S.E. & z & $P>|z|$ & $5 \%$ & $95 \%$ \\
\hline C & 0.01868 & 0.002241 & 8.33 & 0.000 & 0.01428 & 0.0230673 \\
\hline$A R(1)$ & -0.5958 & 0.1001 & -5.95 & 0.000 & -0.7919 & -0.3996712 \\
\hline$A R(2)$ & -0.1074 & 0.1225 & -0.88 & 0.380 & -0.3475 & 0.1326 \\
\hline$A R(3)$ & 0.5716 & 0.09912 & 5.77 & 0.000 & 0.3773 & 0.7659 \\
\hline$A R(4)$ & 0.5448 & 0.1331 & 4.09 & 0.000 & 0.2839 & 0.8057 \\
\hline$A R(5)$ & 0.5275 & 0.1521 & 3.47 & 0.001 & 0.2294 & 0.8257 \\
\hline$M A(1)$ & 1.808 & 0.08857 & 20.42 & 0.000 & 1.635 & 1.982 \\
\hline$M A(2)$ & 2.103 & 0.1608 & 13.08 & 0.000 & 1.788 & 2.418 \\
\hline$M A(3)$ & 1.580 & 0.1916 & 8.25 & 0.000 & 1.205 & 1.956 \\
\hline$M A(4)$ & 0.7696 & 0.1305 & 5.90 & 0.000 & 0.5139 & 1.025 \\
\hline$\sigma$ & 0.0004078 & $6.37 \mathrm{e}-06$ & 63.98 & 0.000 & 0.0003953 & 0.0004203 \\
\hline $\begin{array}{l}\text { No. Obs. }=312 \\
\text { Wald } \chi^{2}(9)=4188.30 \\
P>\chi^{2}=0.0000\end{array}$ & & & & & & \\
\hline
\end{tabular}


Table 5. Akaike Information Criterion for Various $\operatorname{ARIMA}(\mathrm{p}, 0, \mathrm{q})$ Specifications of the Daily Real Exchange Rate

\begin{tabular}{rrrrr}
\hline \hline \multicolumn{4}{r}{ MA Terms } \\
0 & 1 & 2 & 3 \\
\hline
\end{tabular}

\begin{tabular}{lrrrr} 
AR Terms & & & & \\
0 &.. & -64078.71 & -71066.99 & -76355.34 \\
1 & -97684.65 & -97952.48 & -97950.53 & -97954.01 \\
2 & -97942.74 & -97950.55 & -97953.56 & -97954.93 \\
3 & -97946.74 & -97444.59 & -97429.99 & $-97982.25^{*}$ \\
\hline
\end{tabular}

Table 6. Akaike Information Criterion for Various ARIMA(p,1,q) Specifications of the Daily Real Exchange Rate

\begin{tabular}{rrrr}
\hline \hline \multicolumn{4}{c}{ MA Terms } \\
0 & 1 & 2 & 3 \\
\hline
\end{tabular}

\begin{tabular}{lrrrr} 
AR Terms & & & & \\
0 & -97677.29 & -97946.4 & -97944.47 & -97948.07 \\
1 & -97936.41 & -97944.49 & -97947.47 & -97948.97 \\
2 & -97940.56 & -97943.96 & -97946.35 & $-97986.84^{*}$ \\
3 & -97953.77 & -97951.81 & -97980.09 & -97979.15 \\
\hline
\end{tabular}

Table 7. Akaike Information Criterion for Various $\operatorname{ARIMA}(p, 2, q)$ Specifications of the Daily Real Exchange Rate

\begin{tabular}{rrrr}
\hline \hline \multicolumn{4}{r}{ MA Terms } \\
0 & 1 & 2 & 3 \\
\hline
\end{tabular}

\begin{tabular}{lrrrr} 
AR Terms & & & & \\
0 & -92035.80 & -97652.95 & -97049.33 & -97047.42 \\
1 & -94752.23 & -97128.24 & -97131.03 & -97119.69 \\
2 & -95641.35 & -97126.44 & -97144.02 & -97135.66 \\
3 & -96260.75 & -97157.95 & -97165.63 & $-97209.25^{*}$ \\
\hline
\end{tabular}


Table 8. ARIMA $(2,1,3)$ Specification for Daily Real USD/THB Exchange Rate

\begin{tabular}{|c|c|c|c|c|c|c|}
\hline Variable & Coeff. & S.E. & $\mathrm{z}$ & $P>|z|$ & $5 \%$ & $95 \%$ \\
\hline$C$ & $-1.28 \mathrm{e}-06$ & $1.52 \mathrm{e}-06$ & -0.85 & 0.398 & $-4.25 \mathrm{e}-06$ & $1.69 \mathrm{e}-06$ \\
\hline$A R(1)$ & -0.02174 & 0.01311 & -1.66 & 0.097 & -0.04743 & 0.003949 \\
\hline$A R(2)$ & -0.9128 & 0.01172 & -77.88 & 0.000 & -0.9357 & -0.8898 \\
\hline$M A(1)$ & -0.1843 & 0.01263 & -14.59 & 0.000 & -0.2090 & -0.1595 \\
\hline$M A(2)$ & 0.9140 & 0.01114 & 82.06 & 0.000 & 0.8922 & 0.9359 \\
\hline$M A(3)$ & -0.2238 & 0.002636 & -84.91 & 0.000 & -0.2290 & -0.2186 \\
\hline$\sigma$ & 0.0001195 & $1.36 \mathrm{e}-07$ & 876.3 & 0.000 & 0.0001192 & 0.0001197 \\
\hline $\begin{array}{l}\text { No. Obs. }=6436 \\
\text { Wald } \chi^{2}(5)=17452.52 \\
P>\chi^{2}=0.0000\end{array}$ & & & & & & \\
\hline
\end{tabular}




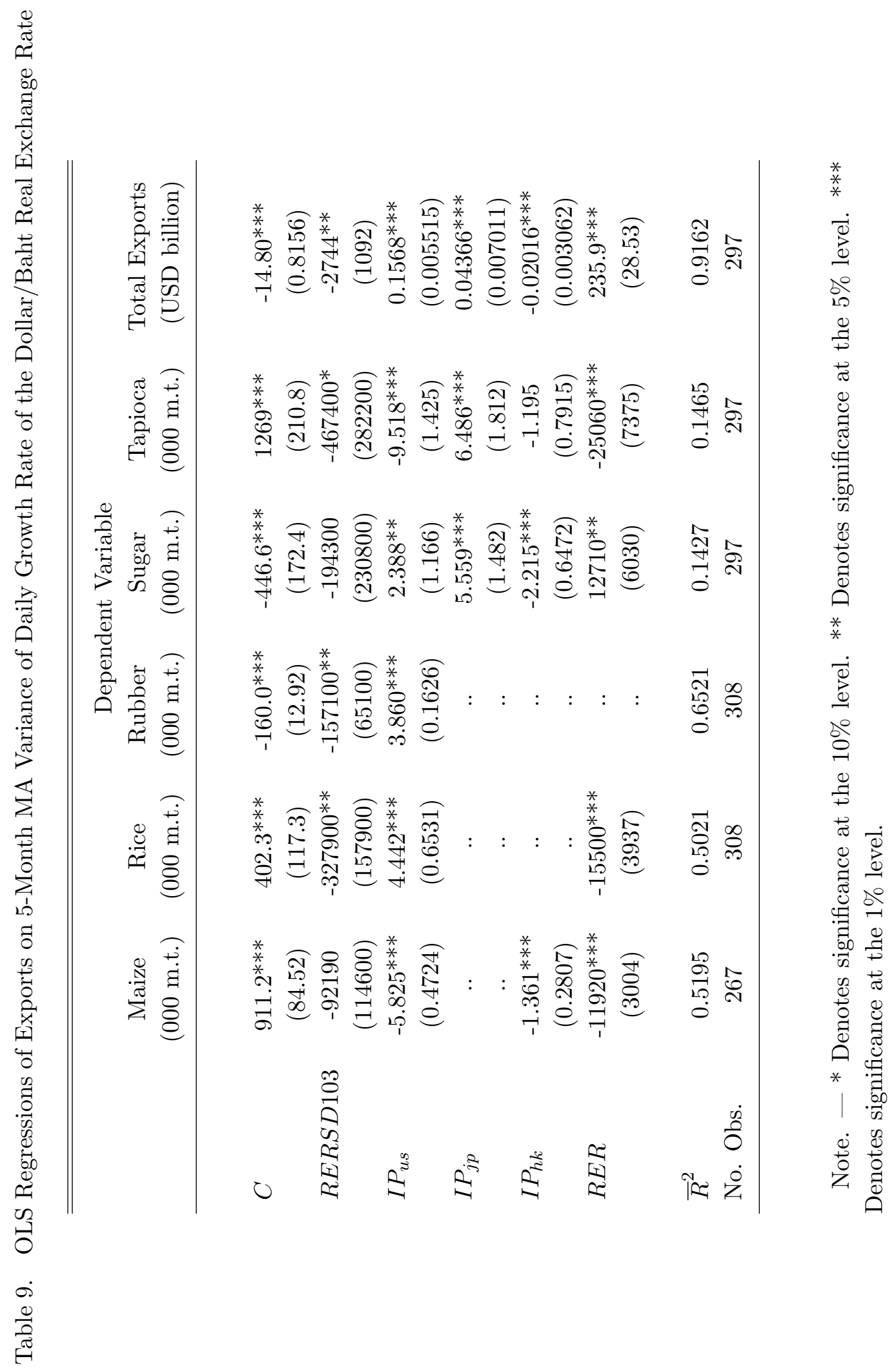




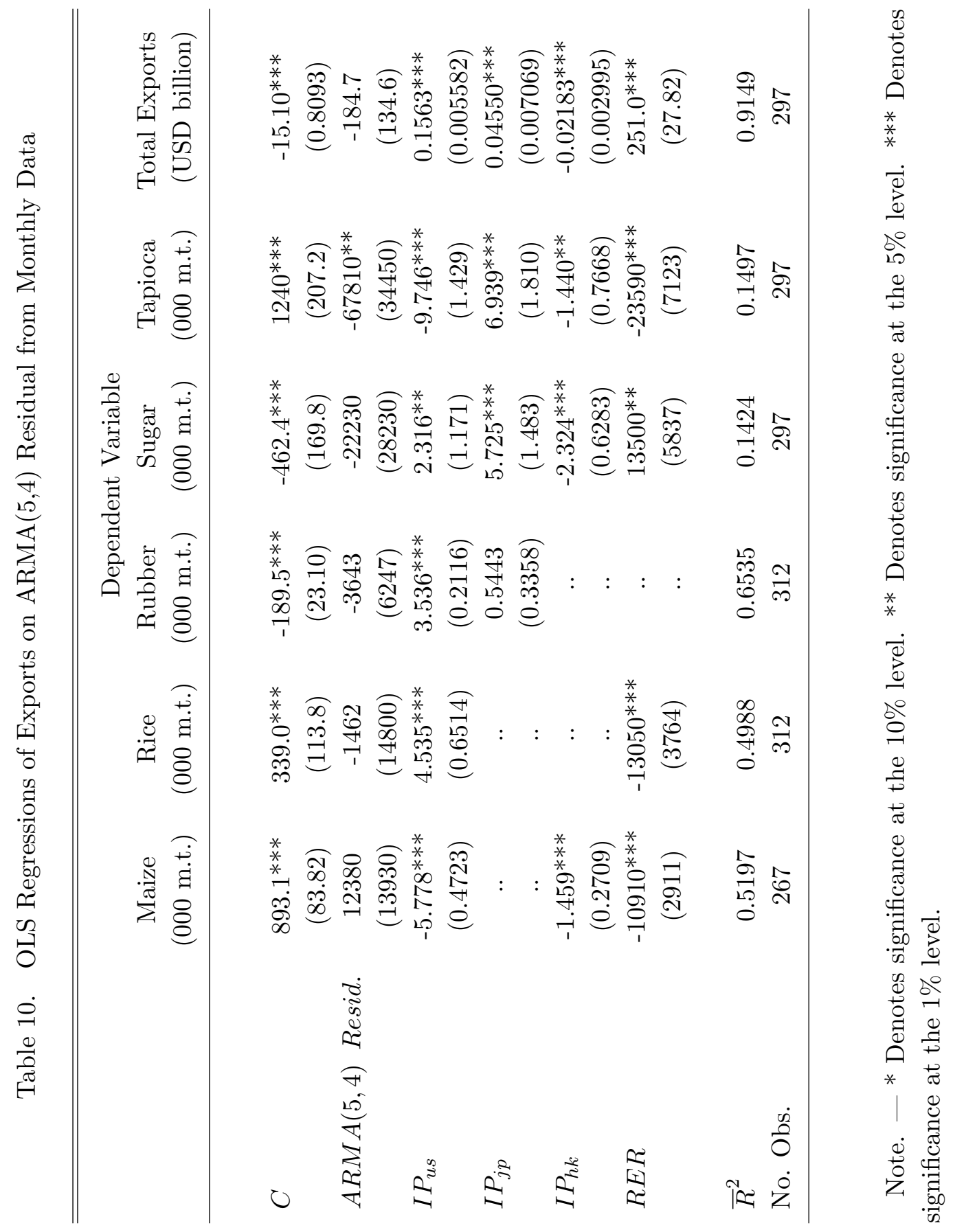




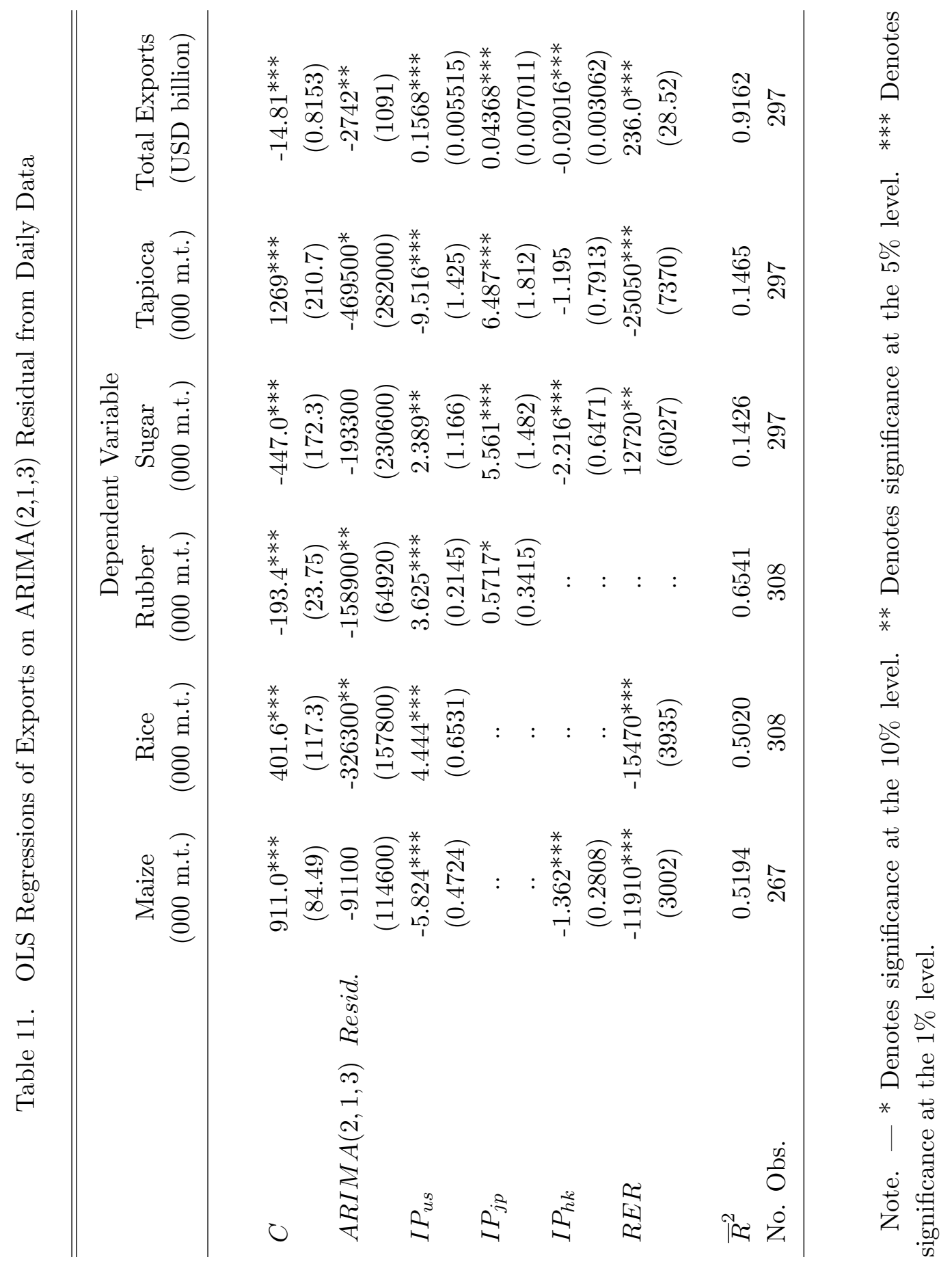




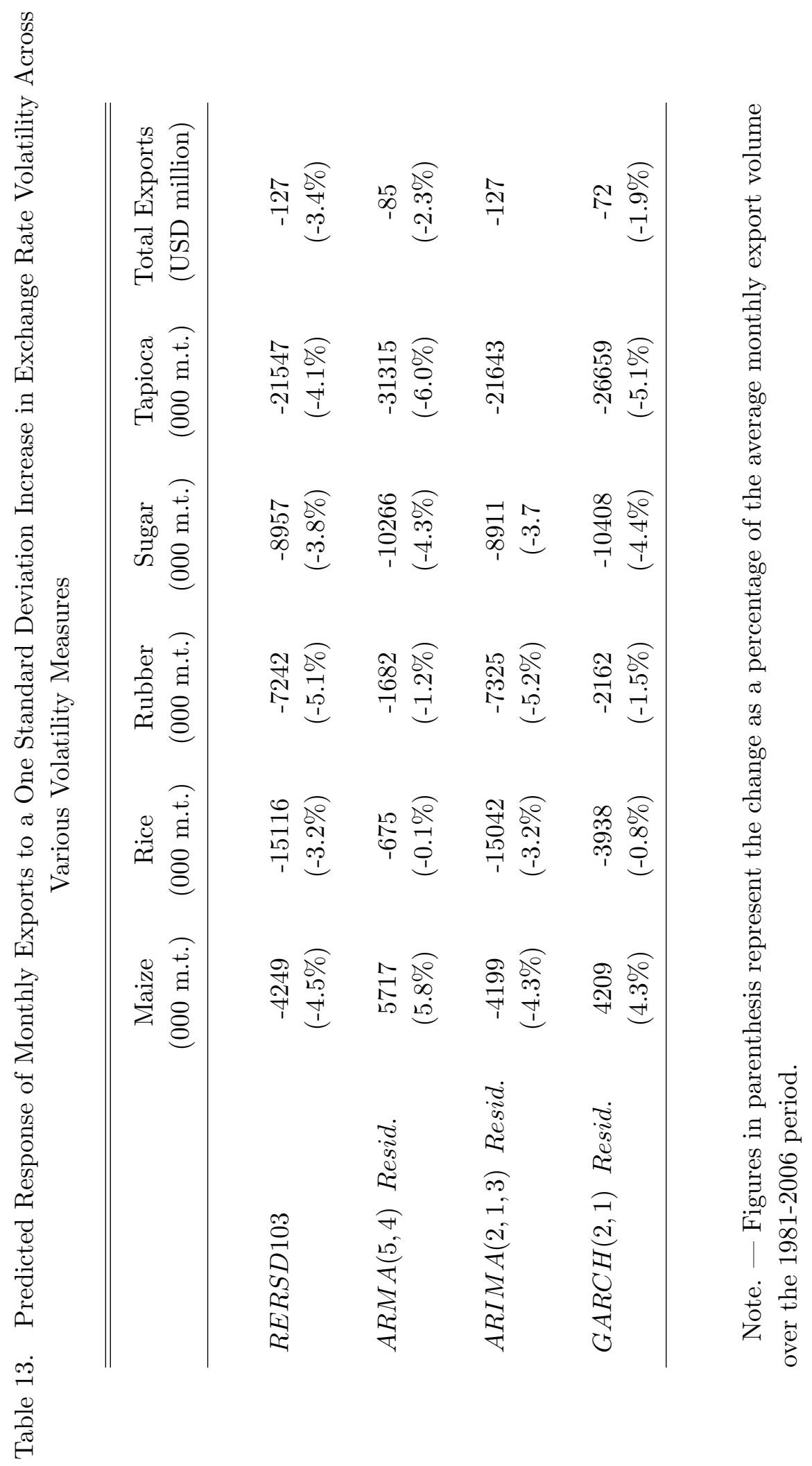


Table 14. OLS Regressions of Production on 5-Month MA Variance of Daily Growth Rate of the Dollar/Baht Real Exchange Rate

\begin{tabular}{|c|c|c|c|c|}
\hline & $\begin{array}{c}\text { Maize } \\
\text { (000 m.t.) }\end{array}$ & $\begin{array}{l}\text { Depender } \\
\text { Rice } \\
\text { (000 m.t.) }\end{array}$ & $\begin{array}{l}\text { Variable } \\
\text { Rubber } \\
\text { (000 m.t.) }\end{array}$ & $\begin{array}{l}\text { Sugar } \\
\text { (000 m.t.) }\end{array}$ \\
\hline C & $\begin{array}{c}1945^{* * *} \\
(398.1)\end{array}$ & $\begin{array}{c}226.0 \\
(3195)\end{array}$ & $\begin{array}{c}96.86 \\
(78.40)\end{array}$ & $\begin{array}{c}-15650^{*} \\
(8810)\end{array}$ \\
\hline$R E R S D 103_{t-4}$ & $\begin{array}{l}. . \\
. .\end{array}$ & $\begin{array}{c}-1.18 \mathrm{e}+07 \\
(1.10 \mathrm{e}+07)\end{array}$ & $\begin{array}{c}432800 \\
(275300)\end{array}$ & $\begin{array}{l}. . \\
. .\end{array}$ \\
\hline$R E R S D 103_{t-5}$ & $\begin{array}{l}-865800 \\
(561400)\end{array}$ & $\begin{array}{c}1.61 \mathrm{e}+07 \\
(1.46 \mathrm{e}+07)\end{array}$ & $\begin{array}{l}-289500 \\
(272200)\end{array}$ & $\begin{array}{c}5.92 \mathrm{e}+07^{* *} \\
(2.59 \mathrm{e}+07)\end{array}$ \\
\hline$R E R S D 103_{t-6}$ & $\begin{array}{l}. . \\
. .\end{array}$ & $\begin{array}{l}. . \\
. .\end{array}$ & $\begin{array}{l}. . \\
. .\end{array}$ & $\begin{array}{c}-7.32 \mathrm{e}+07^{* * * *} \\
(2.63 \mathrm{e}+07)\end{array}$ \\
\hline$R E R S D 103_{t-7}$ & $\begin{array}{l}. . \\
. .\end{array}$ & $\begin{array}{c}-3.12 \mathrm{e}+07^{* *} \\
(1.48 \mathrm{e}+07)\end{array}$ & $\begin{array}{l}. . \\
. .\end{array}$ & $\begin{array}{l}. . \\
. .\end{array}$ \\
\hline$R E R S D 103_{t-8}$ & $\begin{array}{c}2882000^{* * *} \\
(535500)\end{array}$ & $\begin{array}{c}2.25 \mathrm{e}+07^{* *} \\
(1.14 \mathrm{e}+07)\end{array}$ & $\begin{array}{l}. . \\
. .\end{array}$ & $\begin{array}{l}. . \\
. .\end{array}$ \\
\hline$I P_{u s, t-4}$ & $\begin{array}{c}-79.37^{* * *} \\
(22.53)\end{array}$ & $\begin{array}{l}. . \\
. .\end{array}$ & $\begin{array}{c}-12.12^{* *} \\
(4.806)\end{array}$ & $\begin{array}{l}. . \\
. .\end{array}$ \\
\hline$I P_{u s, t-5}$ & $\begin{array}{l}. . \\
. .\end{array}$ & $\begin{array}{c}35.92^{* *} \\
(16.02)\end{array}$ & $\begin{array}{l}. . \\
. .\end{array}$ & $\begin{array}{l}-714.3^{*} \\
(395.0)\end{array}$ \\
\hline$I P_{u s, t-6}$ & $\begin{array}{c}75.53^{* * *} \\
(23.08)\end{array}$ & $\begin{array}{l}. . \\
. .\end{array}$ & $\begin{array}{c}15.31^{* * *} \\
(4.924)\end{array}$ & $\begin{array}{l}. . \\
. .\end{array}$ \\
\hline$I P_{u s, t-7}$ & $\begin{array}{l}. . \\
. .\end{array}$ & $\begin{array}{l}. . \\
. .\end{array}$ & $\begin{array}{l}. . \\
. .\end{array}$ & $\begin{array}{l}. . \\
. .\end{array}$ \\
\hline$I P_{u s, t-8}$ & $\begin{array}{l}. . \\
. .\end{array}$ & $\begin{array}{l}. . \\
. .\end{array}$ & $\begin{array}{l}. . \\
. .\end{array}$ & $\begin{array}{c}926.6^{* *} \\
(408.4)\end{array}$ \\
\hline$I P_{j p, t-4}$ & $\begin{array}{c}-23.97^{* * *} \\
(3.224)\end{array}$ & $\begin{array}{c}-132.3^{* * *} \\
(25.93)\end{array}$ & $\begin{array}{l}. . \\
. .\end{array}$ & $\begin{array}{c}376.9^{* * *} \\
(64.04)\end{array}$ \\
\hline$I P_{j p, t-5}$ & $\begin{array}{c}-14.75^{* * *} \\
(3.000)\end{array}$ & $\begin{array}{c}-53.70^{* *} \\
(26.67)\end{array}$ & $\begin{array}{c}-2.922^{* * *} \\
(0.6077)\end{array}$ & .. \\
\hline$I P_{j p, t-6}$ & $\begin{array}{c}7.548^{* * *} \\
(2.401)\end{array}$ & $\begin{array}{l}. . \\
. .\end{array}$ & $\begin{array}{l}. . \\
. .\end{array}$ & $\begin{array}{l}. . \\
. .\end{array}$ \\
\hline$I P_{j p, t-7}$ & $17.29^{* * *}$ & $-61.81^{* *}$ &.. & $-423.5^{* * *}$ \\
\hline
\end{tabular}


Table 14-Continued

\begin{tabular}{|c|c|c|c|c|}
\hline & \multicolumn{4}{|c|}{ Dependent Variable } \\
\hline & $\begin{array}{c}\text { Maize } \\
\text { (000 m.t.) }\end{array}$ & $\begin{array}{c}\text { Rice } \\
\text { (000 m.t.) }\end{array}$ & $\begin{array}{c}\text { Rubber } \\
\text { (000 m.t.) }\end{array}$ & $\begin{array}{c}\text { Sugar } \\
(000 \text { m.t. })\end{array}$ \\
\hline & $(3.025)$ & $(25.31)$ &.. & $(62.68)$ \\
\hline$I P_{j p, t-8}$ & $\begin{array}{l}7.092^{* *} \\
(2.891)\end{array}$ & $\begin{array}{c}228.2^{* * *} \\
(24.84)\end{array}$ & $\begin{array}{l}1.471^{* *} \\
(0.5715)\end{array}$ & $\begin{array}{c}-101.0^{*} \\
(53.20)\end{array}$ \\
\hline$I P_{h k, t-4}$ & $\begin{array}{c}19.07^{* * * *} \\
(1.861)\end{array}$ & $\begin{array}{c}124.8^{* * *} \\
(16.67)\end{array}$ & $\begin{array}{l}0.4865 \\
(.3545)\end{array}$ & $\begin{array}{l}. . \\
. .\end{array}$ \\
\hline$I P_{h k, t-5}$ & $\begin{array}{l}. . \\
. .\end{array}$ & $\begin{array}{l}. . \\
. .\end{array}$ & $\begin{array}{l}. . \\
. .\end{array}$ & $\begin{array}{c}230.1^{* * *} \\
(45.46)\end{array}$ \\
\hline$I P_{h k, t-6}$ & $\begin{array}{c}-23.81^{* * *} \\
(2.875)\end{array}$ & $\begin{array}{c}-91.86^{* * *} \\
(23.40)\end{array}$ & $\begin{array}{c}-1.356^{* * *} \\
(0.4858)\end{array}$ & $\begin{array}{c}185.7^{* * *} \\
(51.61)\end{array}$ \\
\hline$I P_{h k, t-7}$ & $\begin{array}{c}-14.63^{* * *} \\
(2.344)\end{array}$ & $\begin{array}{c}94.84^{* * *} \\
(21.38)\end{array}$ & $\begin{array}{c}-1.318^{* * *} \\
(.4171)\end{array}$ & $\begin{array}{l}. . \\
. .\end{array}$ \\
\hline$I P_{h k, t-8}$ & $\begin{array}{l}. . \\
. .\end{array}$ & $\begin{array}{c}-116.2^{* * *} \\
(18.83)\end{array}$ & $\begin{array}{l}. . \\
. .\end{array}$ & $\begin{array}{c}-166.9^{* * *} \\
(36.72)\end{array}$ \\
\hline$R E R_{t-4}$ & $\begin{array}{l}. . \\
. .\end{array}$ & $\begin{array}{c}-413600^{* *} \\
(197600)\end{array}$ & $\begin{array}{l}11160 \\
(7346)\end{array}$ & $\begin{array}{l}. . \\
. .\end{array}$ \\
\hline$R E R_{t-5}$ & $\begin{array}{l}. . \\
. .\end{array}$ & $\begin{array}{l}. . \\
. .\end{array}$ & $\begin{array}{l}-9273 \\
(8747)\end{array}$ & $\begin{array}{c}-577400^{* *} \\
(245600)\end{array}$ \\
\hline$R E R_{t-6}$ & $\begin{array}{c}24290 \\
(23370)\end{array}$ & $\begin{array}{l}390400 * \\
(202500)\end{array}$ & $\begin{array}{l}. . \\
. .\end{array}$ & $\begin{array}{l}. . \\
. .\end{array}$ \\
\hline$R E R_{t-7}$ & $\begin{array}{l}. . \\
. .\end{array}$ & $\begin{array}{l}. . \\
. .\end{array}$ & $\begin{array}{l}8471^{*} \\
(4937)\end{array}$ & $\begin{array}{l}. . \\
. .\end{array}$ \\
\hline$R E R_{t-8}$ & $\begin{array}{c}59200^{* *} \\
(23880)\end{array}$ & $\begin{array}{l}. . \\
. .\end{array}$ & $\begin{array}{l}. . \\
. .\end{array}$ & $\begin{array}{l}. . \\
. .\end{array}$ \\
\hline $\bar{R}^{2}$ & 0.7345 & 0.5912 & 0.6379 & 0.4085 \\
\hline No. Obs. & 228 & 228 & 228 & 228 \\
\hline
\end{tabular}

Note. — * Denotes significance at the $10 \%$ level. ${ }^{* *}$ Denotes significance at the $5 \%$ level. $* * *$ Denotes significance at the $1 \%$ level. 
Table 15. OLS Regressions of Production on ARIMA(5,0,4) Residual from Monthly Data

\begin{tabular}{|c|c|c|c|c|}
\hline & \multicolumn{4}{|c|}{ Dependent Variable } \\
\hline & $\begin{array}{c}\text { Maize } \\
\text { (000 m.t.) }\end{array}$ & $\begin{array}{c}\text { Rice } \\
\text { (000 m.t.) }\end{array}$ & $\begin{array}{l}\text { Rubber } \\
\text { (000 m.t.) }\end{array}$ & $\begin{array}{c}\text { Sugar } \\
\text { (000 m.t.) }\end{array}$ \\
\hline$C$ & $\begin{array}{c}2049 * * * \\
(428.5)\end{array}$ & $\begin{array}{c}3.566 \\
(3188)\end{array}$ & $\begin{array}{c}83.70 \\
(77.19)\end{array}$ & $\begin{array}{l}-12140 \\
(9408)\end{array}$ \\
\hline $\operatorname{ARIMA}(5,0,4)$ Resid. $_{\cdot t-4}$ & .. & $\begin{array}{l}-483900 \\
(351900)\end{array}$ & .. & $\begin{array}{l}. . \\
. .\end{array}$ \\
\hline$A R I M A(5,0,4)$ Resid.t $_{\cdot 5}$ & $\begin{array}{l}. . \\
. .\end{array}$ & $\begin{array}{c}469800 \\
(357900)\end{array}$ & $\begin{array}{l}11880 \\
(9505)\end{array}$ & $\begin{array}{c}1935000^{* *} \\
(975000)\end{array}$ \\
\hline $\operatorname{ARIMA}(5,0,4)$ Resid.t-6 $_{\cdot t}$ & $\begin{array}{l}. . \\
. .\end{array}$ & $\begin{array}{l}. . \\
. .\end{array}$ & $\begin{array}{l}14060 \\
(9822)\end{array}$ & $\begin{array}{l}. . \\
. .\end{array}$ \\
\hline$A R I M A(5,0,4)$ Resid.t$_{\cdot t-7}$ & $\begin{array}{c}72050 \\
(47420)\end{array}$ & $\begin{array}{l}-535000 \\
(351700)\end{array}$ & $\begin{array}{l}13010 \\
(9415)\end{array}$ & $\begin{array}{l}. . \\
. .\end{array}$ \\
\hline $\operatorname{ARIMA}(5,0,4)$ Resid.t$_{\cdot-8}$ & $\begin{array}{c}101100^{* *} \\
(49170)\end{array}$ & $\begin{array}{l}-614000^{*} \\
(347500)\end{array}$ & .. & $\begin{array}{l}-1037000 \\
(1032000)\end{array}$ \\
\hline$I P_{u s, t-4}$ & $\begin{array}{c}-72.83^{* * *} \\
(24.24)\end{array}$ & $\begin{array}{l}. . \\
. .\end{array}$ & $\begin{array}{c}-13.13^{* * *} \\
(4.733)\end{array}$ & $\begin{array}{l}. . \\
. .\end{array}$ \\
\hline$I P_{u s, t-5}$ & $\begin{array}{l}. . \\
. .\end{array}$ & $\begin{array}{c}36.81^{* *} \\
(15.46)\end{array}$ & $\begin{array}{l}. . \\
. .\end{array}$ & $\begin{array}{c}-1178^{* * *} \\
(395.7)\end{array}$ \\
\hline$I P_{u s, t-6}$ & $\begin{array}{l}72.24^{*} \\
(43.25)\end{array}$ & $\begin{array}{l}. . \\
. .\end{array}$ & $\begin{array}{c}16.39 * * * \\
(4.861)\end{array}$ & $\begin{array}{l}. . \\
. .\end{array}$ \\
\hline$I P_{u s, t-7}$ & $\begin{array}{c}55.48 \\
(47.18)\end{array}$ & $\begin{array}{l}. . \\
. .\end{array}$ & $\begin{array}{l}. . \\
. .\end{array}$ & $\begin{array}{l}. . \\
. .\end{array}$ \\
\hline$I P_{u s, t-8}$ & $\begin{array}{c}-58.21^{*} \\
(34.10)\end{array}$ & $\begin{array}{l}. . \\
. .\end{array}$ & $\begin{array}{l}. . \\
. .\end{array}$ & $\begin{array}{c}1375^{* * *} \\
(408.5)\end{array}$ \\
\hline$I P_{j p, t-4}$ & $\begin{array}{c}-27.63^{* * *} \\
(3.456)\end{array}$ & $\begin{array}{c}-128.5^{* * *} \\
(25.59)\end{array}$ & $\begin{array}{l}. . \\
. .\end{array}$ & $\begin{array}{c}480.3^{* * *} \\
(81.63)\end{array}$ \\
\hline$I P_{j p, t-5}$ & $\begin{array}{c}-17.88^{* * *} \\
(3.659)\end{array}$ & $\begin{array}{c}-63.60^{* *} \\
(25.82)\end{array}$ & $\begin{array}{c}-2.997^{* * *} \\
(0.6108)\end{array}$ & $\begin{array}{c}117.5 \\
(80.77)\end{array}$ \\
\hline$I P_{j p, t-6}$ & $\begin{array}{c}7.281^{* * *} \\
(2.650)\end{array}$ & $\begin{array}{l}. . \\
. .\end{array}$ & $\begin{array}{l}. . \\
. .\end{array}$ & $\begin{array}{c}-57.64 \\
(56.86)\end{array}$ \\
\hline$I P_{j p, t-7}$ & $\begin{array}{c}21.56^{* * *} \\
(3.557)\end{array}$ & $\begin{array}{c}-61.94^{* *} \\
(25.13)\end{array}$ & $\begin{array}{l}. . \\
. .\end{array}$ & $\begin{array}{c}-524.5^{* * *} \\
(76.44)\end{array}$ \\
\hline
\end{tabular}


Table 15-Continued

\begin{tabular}{|c|c|c|c|c|}
\hline & \multicolumn{4}{|c|}{ Dependent Variable } \\
\hline & $\begin{array}{c}\text { Maize } \\
\text { (000 m.t.) }\end{array}$ & $\begin{array}{c}\text { Rice } \\
\text { (000 m.t.) }\end{array}$ & $\begin{array}{c}\text { Rubber } \\
\text { (000 m.t.) }\end{array}$ & $\begin{array}{c}\text { Sugar } \\
\text { (000 m.t.) }\end{array}$ \\
\hline$I P_{j p, t-8}$ & $\begin{array}{c}9.013^{* * *} \\
(3.431)\end{array}$ & $\begin{array}{c}235.6^{* * *} \\
(24.72)\end{array}$ & $\begin{array}{c}1.523^{* * *} \\
(0.5645)\end{array}$ & $\begin{array}{c}-176.5^{* *} \\
(76.40)\end{array}$ \\
\hline$I P_{h k, t-4}$ & $\begin{array}{c}22.56^{* * *} \\
(2.159)\end{array}$ & $\begin{array}{c}130.0^{* * *} \\
(15.90)\end{array}$ & $\begin{array}{c}0.4202 \\
(0.3476)\end{array}$ & $\begin{array}{c}-99.23^{*} \\
(57.37)\end{array}$ \\
\hline$I P_{h k, t-5}$ & $\begin{array}{l}. . \\
. .\end{array}$ & $\begin{array}{l}. . \\
. .\end{array}$ & $\begin{array}{l}. . \\
. .\end{array}$ & $\begin{array}{c}249.8^{* * *} \\
(70.35)\end{array}$ \\
\hline$I P_{h k, t-6}$ & $\begin{array}{c}-27.29^{* * *} \\
(3.167)\end{array}$ & $\begin{array}{c}-96.87^{* * *} \\
(23.02)\end{array}$ & $\begin{array}{c}-1.350^{* * *} \\
(0.4843)\end{array}$ & $\begin{array}{c}309.5^{* * *} \\
(71.13)\end{array}$ \\
\hline$I P_{h k, t-7}$ & $\begin{array}{c}-12.96^{* * *} \\
(2.993)\end{array}$ & $\begin{array}{c}96.94^{* * *} \\
(21.40)\end{array}$ & $\begin{array}{c}-1.334^{* * *} \\
(0.4084)\end{array}$ & $\begin{array}{l}-76.55 \\
(69.67)\end{array}$ \\
\hline$I P_{h k, t-8}$ & $\begin{array}{c}2.881 \\
(2.443)\end{array}$ & $\begin{array}{c}-115.9^{* * *} \\
(17.94)\end{array}$ & $\begin{array}{l}. . \\
. .\end{array}$ & $\begin{array}{c}-214.5^{* * *} \\
(54.63)\end{array}$ \\
\hline$R E R_{t-4}$ & $\begin{array}{l}. . \\
. .\end{array}$ & $\begin{array}{l}-197300 \\
(148200)\end{array}$ & $\begin{array}{c}5411 \\
(4100)\end{array}$ & $\begin{array}{l}. . \\
. .\end{array}$ \\
\hline$R E R_{t-5}$ & $\begin{array}{l}. . \\
. .\end{array}$ & $\begin{array}{l}. . \\
. .\end{array}$ & $\begin{array}{l}. . \\
. .\end{array}$ & $\begin{array}{l}. . \\
. .\end{array}$ \\
\hline$R E R_{t-6}$ & $\begin{array}{l}. . \\
. .\end{array}$ & $\begin{array}{l}. . \\
. .\end{array}$ & $\begin{array}{l}. . \\
. .\end{array}$ & $\begin{array}{l}-973900 \\
(732100)\end{array}$ \\
\hline$R E R_{t-7}$ & $\begin{array}{c}53330^{* * *} \\
(11900)\end{array}$ & $\begin{array}{c}161900 \\
(146800)\end{array}$ & $\begin{array}{c}5889 \\
(4070)\end{array}$ & $\begin{array}{c}814000 \\
(753900)\end{array}$ \\
\hline$R E R_{t-8}$ & $\begin{array}{l}. \\
.\end{array}$ & $\begin{array}{l}. . \\
. .\end{array}$ & $\begin{array}{l}. . \\
. .\end{array}$ & $\begin{array}{l}. \\
. .\end{array}$ \\
\hline $\bar{R}^{2}$ & 0.6932 & 0.5936 & 0.6405 & 0.3970 \\
\hline No. Obs. & 228 & 228 & 228 & 228 \\
\hline
\end{tabular}

Note. - * Denotes significance at the $10 \%$ level. ${ }^{* *}$ Denotes significance at the $5 \%$ level. *** Denotes significance at the $1 \%$ level. 
Table 16. OLS Regressions of Production on $\operatorname{ARIMA}(2,1,3)$ Residual from Daily Data

\begin{tabular}{|c|c|c|c|c|}
\hline & $\begin{array}{c}\text { Maize } \\
\text { (000 m.t.) }\end{array}$ & $\begin{array}{l}\text { Depender } \\
\text { Rice } \\
\text { (000 m.t.) }\end{array}$ & $\begin{array}{l}\text { Variable } \\
\text { Rubber } \\
\text { (000 m.t.) }\end{array}$ & $\begin{array}{c}\text { Sugar } \\
\text { (000 m.t.) }\end{array}$ \\
\hline$C$ & $\begin{array}{c}1942^{* * *} \\
(398.2)\end{array}$ & $\begin{array}{l}191.9 \\
(3198)\end{array}$ & $\begin{array}{c}97.28 \\
(78.40)\end{array}$ & $\begin{array}{c}-16700^{*} \\
(8884)\end{array}$ \\
\hline $\operatorname{ARIMA}(2,1,3)$ Resid $_{\cdot t-4}$ & $\begin{array}{l}. . \\
. .\end{array}$ & $\begin{array}{l}-1.18 \mathrm{e}+07 \\
(1.10 \mathrm{e}+07)\end{array}$ & $\begin{array}{c}435100 \\
(275900)\end{array}$ & $\begin{array}{l}. . \\
. .\end{array}$ \\
\hline$A R I M A(2,1,3)$ Resid.t-5 & $\begin{array}{l}-897400 \\
(560500)\end{array}$ & $\begin{array}{c}1.61 \mathrm{e}+07 \\
(1.47 \mathrm{e}+07)\end{array}$ & $\begin{array}{l}-290700 \\
(273100)\end{array}$ & $\begin{array}{c}5.81 \mathrm{e}+07^{* *} \\
(2.60 \mathrm{e}+07)\end{array}$ \\
\hline$A R I M A(2,1,3)$ Resid.t-6 $_{\cdot}$ & $\begin{array}{l}. . \\
. .\end{array}$ & $\begin{array}{l}. . \\
. .\end{array}$ & $\begin{array}{l}. . \\
. .\end{array}$ & $\begin{array}{c}-7.10 \mathrm{e}+07^{* * *} \\
(2.66 \mathrm{e}+07)\end{array}$ \\
\hline$A R I M A(2,1,3) \quad$ Resid.t-7 & $\begin{array}{l}. . \\
.\end{array}$ & $\begin{array}{c}-3.06 \mathrm{e}+07^{* *} \\
(1.49 \mathrm{e}+07)\end{array}$ & $\begin{array}{l}. . \\
. .\end{array}$ & $\begin{array}{l}. \cdot \\
. .\end{array}$ \\
\hline$A R I M A(2,1,3)$ Resid.t-8 $_{\cdot}$ & $\begin{array}{c}2906000^{* * *} \\
(535400)\end{array}$ & $\begin{array}{c}2.18 \mathrm{e}+07^{*} \\
(1.14 \mathrm{e}+07)\end{array}$ & $\begin{array}{l}. . \\
. .\end{array}$ & $\begin{array}{l}. . \\
. .\end{array}$ \\
\hline$I P_{u s, t-4}$ & $\begin{array}{c}-79.49^{* * *} \\
(22.52)\end{array}$ & $\begin{array}{l}. . \\
. .\end{array}$ & $\begin{array}{c}-12.12^{* *} \\
(4.805)\end{array}$ & $\begin{array}{l}. . \\
. .\end{array}$ \\
\hline$I P_{u s, t-5}$ & $\begin{array}{l}. . \\
. .\end{array}$ & $\begin{array}{l}36.16^{* *} \\
(16.02)\end{array}$ & .. & $\begin{array}{l}-737.5^{*} \\
(395.5)\end{array}$ \\
\hline$I P_{u s, t-6}$ & $\begin{array}{c}75.68^{* * * *} \\
(23.07)\end{array}$ & $\begin{array}{l}. . \\
. .\end{array}$ & $\begin{array}{c}15.30^{* * *} \\
(4.923)\end{array}$ & $\begin{array}{l}. . \\
. .\end{array}$ \\
\hline$I P_{u s, t-7}$ & $\begin{array}{l}. . \\
. .\end{array}$ & $\begin{array}{l}. . \\
. .\end{array}$ & $\begin{array}{l}. . \\
. .\end{array}$ & $\begin{array}{l}. . \\
. .\end{array}$ \\
\hline$I P_{u s, t-8}$ & $\begin{array}{l}. . \\
. .\end{array}$ & $\begin{array}{l}. . \\
. .\end{array}$ & $\begin{array}{l}. . \\
. .\end{array}$ & $\begin{array}{c}941.5^{* *} \\
(408.5)\end{array}$ \\
\hline$I P_{j p, t-4}$ & $\begin{array}{c}-23.96^{* * *} \\
(3.223)\end{array}$ & $\begin{array}{c}-132.7^{* * *} \\
(25.95)\end{array}$ & $\begin{array}{l}. . \\
. .\end{array}$ & $\begin{array}{c}378.2^{\text {*** }} \\
(64.00)\end{array}$ \\
\hline$I P_{j p, t-5}$ & $\begin{array}{c}-14.75^{* * *} \\
(2.999)\end{array}$ & $\begin{array}{c}-53.81^{* *} \\
(26.69)\end{array}$ & $\begin{array}{c}-2.923^{* * *} \\
(0.6076)\end{array}$ & $\begin{array}{c}73.50 \\
(71.90)\end{array}$ \\
\hline$I P_{j p, t-6}$ & $\begin{array}{c}7.531^{* * *} \\
(2.400)\end{array}$ & $\begin{array}{l}. . \\
. .\end{array}$ & $\begin{array}{l}. \\
. .\end{array}$ & .. \\
\hline$I P_{j p, t-7}$ & $\begin{array}{c}17.29^{* * *} \\
(3.024)\end{array}$ & $\begin{array}{c}-61.35^{* *} \\
(25.32)\end{array}$ & $\begin{array}{l}. . \\
. .\end{array}$ & $\begin{array}{c}-427.4^{* * *} \\
(62.77)\end{array}$ \\
\hline
\end{tabular}


Table 16-Continued

\begin{tabular}{|c|c|c|c|c|}
\hline & \multicolumn{4}{|c|}{ Dependent Variable } \\
\hline & $\begin{array}{c}\text { Maize } \\
\text { (000 m.t.) }\end{array}$ & $\begin{array}{c}\text { Rice } \\
\text { (000 m.t.) }\end{array}$ & $\begin{array}{c}\text { Rubber } \\
\text { (000 m.t.) }\end{array}$ & $\begin{array}{c}\text { Sugar } \\
(000 \text { m.t. })\end{array}$ \\
\hline$I P_{j p, t-8}$ & $\begin{array}{l}7.084^{* *} \\
(2.890)\end{array}$ & $\begin{array}{c}228.1^{* * *} \\
(24.85)\end{array}$ & $\begin{array}{l}1.471^{* *} \\
(0.5713)\end{array}$ & $\begin{array}{c}-146.9^{* *} \\
(69.14)\end{array}$ \\
\hline$I P_{h k, t-4}$ & $\begin{array}{c}19.10^{* * *} \\
(1.860)\end{array}$ & $\begin{array}{c}125.2^{* * *} \\
(16.66)\end{array}$ & $\begin{array}{c}0.4880 \\
(0.3545)\end{array}$ & .. \\
\hline$I P_{h k, t-5}$ & $\begin{array}{l}. . \\
. .\end{array}$ & $\begin{array}{l}. . \\
. .\end{array}$ & $\begin{array}{l}. . \\
. .\end{array}$ & $\begin{array}{c}200.3^{* * *} \\
(54.16)\end{array}$ \\
\hline$I P_{h k, t-6}$ & $\begin{array}{c}-23.84^{* * *} \\
(2.873)\end{array}$ & $\begin{array}{c}-92.29 * * * \\
(23.39)\end{array}$ & $\begin{array}{c}-1.359^{* * *} \\
(0.4858)\end{array}$ & $\begin{array}{c}225.3^{\text {*** }} \\
(64.97)\end{array}$ \\
\hline$I P_{h k, t-7}$ & $\begin{array}{c}-14.61^{* * *} \\
(2.343)\end{array}$ & $\begin{array}{c}94.81^{* * *} \\
(21.39)\end{array}$ & $\begin{array}{c}-1.315^{* * *} \\
(0.4171)\end{array}$ & .. \\
\hline$I P_{h k, t-8}$ & $\begin{array}{l}. . \\
. .\end{array}$ & $\begin{array}{c}-115.9^{* * *} \\
(18.84)\end{array}$ & $\begin{array}{l}. . \\
. .\end{array}$ & $\begin{array}{c}-183.4^{* * *} \\
(40.22)\end{array}$ \\
\hline$R E R_{t-4}$ & $\begin{array}{l}. . \\
. .\end{array}$ & $\begin{array}{c}-407800^{* *} \\
(197300)\end{array}$ & $\begin{array}{l}11210 \\
(7345)\end{array}$ & $\begin{array}{l}. . \\
. .\end{array}$ \\
\hline$R E R_{t-5}$ & $\begin{array}{l}. . \\
. .\end{array}$ & $\begin{array}{l}. . \\
. .\end{array}$ & $\begin{array}{l}-9310 \\
(8748)\end{array}$ & $\begin{array}{c}-574500^{* *} \\
(245600)\end{array}$ \\
\hline$R E R_{t-6}$ & $\begin{array}{c}24430 \\
(23350)\end{array}$ & $\begin{array}{l}384000^{*} \\
(202100)\end{array}$ & $\begin{array}{l}. . \\
. .\end{array}$ & $\begin{array}{l}. . \\
. .\end{array}$ \\
\hline$R E R_{t-7}$ & $\begin{array}{l}. . \\
. .\end{array}$ & $\begin{array}{l}. . \\
. .\end{array}$ & $\begin{array}{l}8439^{*} \\
(4937)\end{array}$ & $\begin{array}{l}. . \\
. .\end{array}$ \\
\hline$R E R_{t-8}$ & $\begin{array}{c}59090 * * \\
(23870)\end{array}$ & $\begin{array}{l}. . \\
. .\end{array}$ & $\begin{array}{l}. . \\
. .\end{array}$ & $\begin{array}{l}. . \\
. .\end{array}$ \\
\hline $\bar{R}^{2}$ & 0.7346 & 0.5907 & 0.6380 & 0.4089 \\
\hline No. Obs. & 228 & 228 & 228 & 228 \\
\hline
\end{tabular}

Note. — * Denotes significance at the $10 \%$ level. ** Denotes significance at the $5 \%$ level. $* * *$ Denotes significance at the $1 \%$ level. 
Table 17. OLS Regressions of Production on Conditional Time Variance Estimated by $\operatorname{GARCH}(2,1)$ on Monthly Data

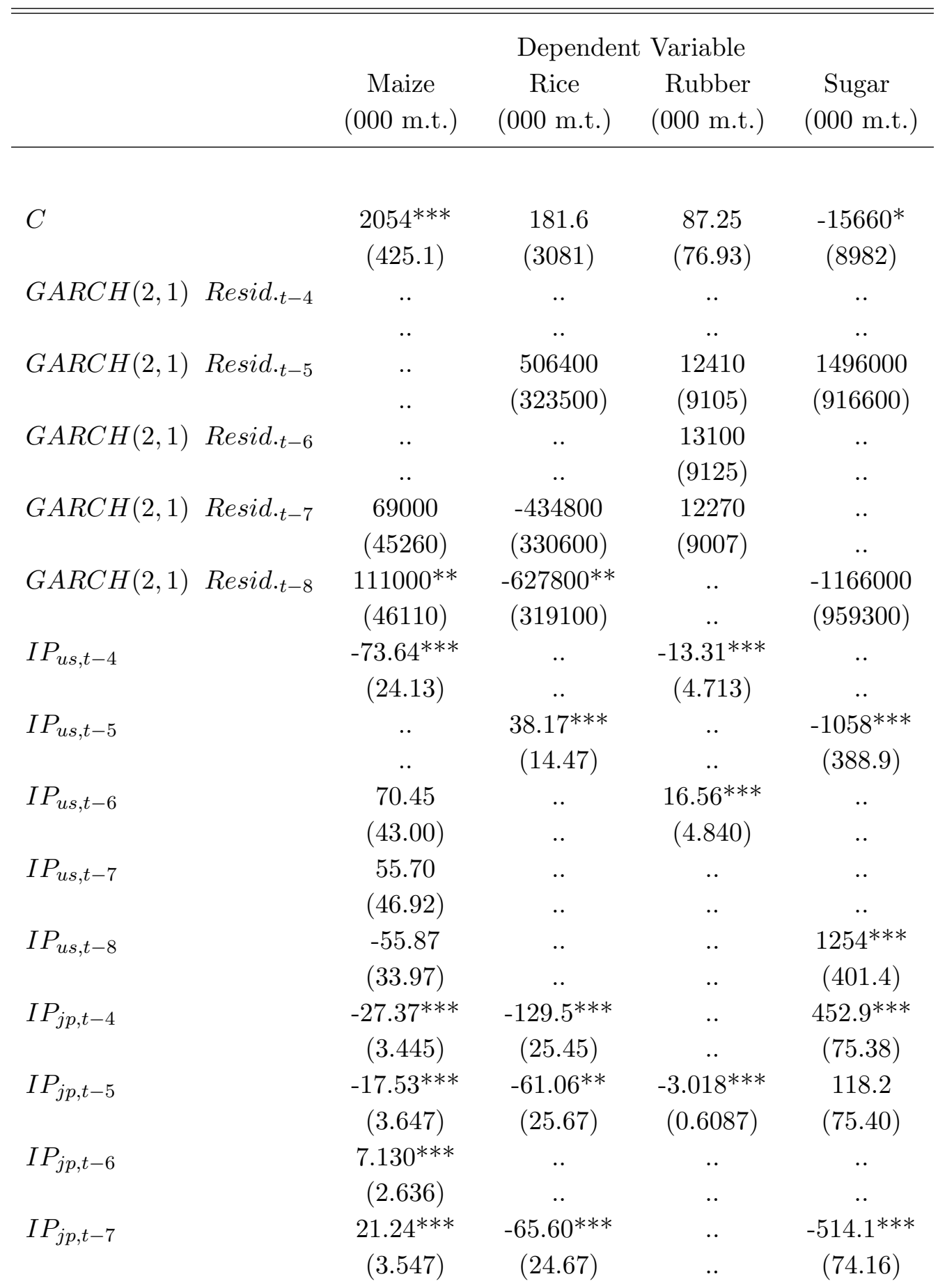


Table 17-Continued

\begin{tabular}{|c|c|c|c|c|}
\hline & \multicolumn{4}{|c|}{ Dependent Variable } \\
\hline & $\begin{array}{c}\text { Maize } \\
\text { (000 m.t.) }\end{array}$ & $\begin{array}{c}\text { Rice } \\
\text { (000 m.t.) }\end{array}$ & $\begin{array}{c}\text { Rubber } \\
\text { (000 m.t.) }\end{array}$ & $\begin{array}{l}\text { Sugar } \\
\text { (000 m.t.) }\end{array}$ \\
\hline$I P_{j p, t-8}$ & $\begin{array}{c}8.831^{* *} \\
(3.401)\end{array}$ & $\begin{array}{c}232.2^{* * *} \\
(24.40)\end{array}$ & $\begin{array}{c}1.540^{* * *} \\
(0.5629)\end{array}$ & $\begin{array}{c}-182.5^{* *} \\
(72.68)\end{array}$ \\
\hline$I P_{h k, t-4}$ & $\begin{array}{c}22.26^{* * *} \\
(2.160)\end{array}$ & $\begin{array}{c}126.4^{* * *} \\
(15.02)\end{array}$ & $\begin{array}{c}0.4143 \\
(0.3460)\end{array}$ & $\begin{array}{l}-73.78 \\
(54.58)\end{array}$ \\
\hline$I P_{h k, t-5}$ & $\begin{array}{l}. . \\
. .\end{array}$ & $\begin{array}{l}. . \\
. .\end{array}$ & $\begin{array}{l}. . \\
. .\end{array}$ & $\begin{array}{c}223.7^{* * *} \\
(63.94)\end{array}$ \\
\hline$I P_{h k, t-6}$ & $\begin{array}{c}-26.93^{* * *} \\
(3.163)\end{array}$ & $\begin{array}{c}-93.22^{* * *} \\
(22.80)\end{array}$ & $\begin{array}{c}-1.333^{* * *} \\
(.4827)\end{array}$ & $\begin{array}{c}276.3^{* * *} \\
(67.62)\end{array}$ \\
\hline$I P_{h k, t-7}$ & $\begin{array}{c}-12.97^{* * *} \\
(2.976)\end{array}$ & $\begin{array}{c}94.59^{* * *} \\
(21.32)\end{array}$ & $\begin{array}{c}-1.385^{* * *} \\
(0.4084)\end{array}$ & $\begin{array}{l}. . \\
. .\end{array}$ \\
\hline$I P_{h k, t-8}$ & $\begin{array}{c}2.554 \\
(2.442)\end{array}$ & $\begin{array}{c}-118.1^{* * *} \\
(17.48)\end{array}$ & $\begin{array}{l}. . \\
. .\end{array}$ & $\begin{array}{c}-241.4^{* * *} \\
(42.50)\end{array}$ \\
\hline$R E R_{t-4}$ & $\begin{array}{l}. . \\
. .\end{array}$ & $\begin{array}{l}. . \\
. .\end{array}$ & $\begin{array}{c}4618 \\
(3910)\end{array}$ & $\begin{array}{l}. . \\
. .\end{array}$ \\
\hline$R E R_{t-5}$ & $\begin{array}{l}. . \\
. .\end{array}$ & $\begin{array}{l}. . \\
. .\end{array}$ & $\begin{array}{l}. . \\
. .\end{array}$ & $\begin{array}{l}. . \\
. .\end{array}$ \\
\hline$R E R_{t-6}$ & $\begin{array}{l}. . \\
. .\end{array}$ & $\begin{array}{l}. . \\
. .\end{array}$ & $\begin{array}{l}. . \\
. .\end{array}$ & $\begin{array}{l}-243400 \\
(231800)\end{array}$ \\
\hline$R E R_{t-7}$ & $\begin{array}{c}55211^{* * *} \\
(11890)\end{array}$ & $\begin{array}{l}. . \\
. .\end{array}$ & $\begin{array}{l}6877^{*} \\
(3950)\end{array}$ & $\begin{array}{l}. . \\
. .\end{array}$ \\
\hline$R E R_{t-8}$ & $\begin{array}{l}. . \\
. .\end{array}$ & $\begin{array}{l}. . \\
. .\end{array}$ & $\begin{array}{l}. . \\
. .\end{array}$ & $\begin{array}{l}. . \\
. .\end{array}$ \\
\hline $\bar{R}^{2}$ & 0.6960 & 0.5952 & 0.6428 & 0.3977 \\
\hline No. Obs. & 228 & 228 & 228 & 228 \\
\hline
\end{tabular}

Note. — * Denotes significance at the $10 \%$ level. ** Denotes significance at the $5 \%$ level. $* * *$ Denotes significance at the $1 \%$ level. 


\section{REFERENCES}

Arize, Augustine C. "The Effects of Exchange-Rate Volatility on U.S. Exports: An Empirical Investigation." Southern Economic Journal, July 1995, 62(1), pp. 34-43.

Arize, Augustine C.; Osang, Thomas and Slottje, Daniel J. "Exchange-Rate Volatility and Foreign Trade: Evidence from Thirteen LDC's" Journal of Business and Economic Statistics, January 2000, 18(1), pp. 10-17.

Asseery, A. and Peel, D.A. "The Effects of Exchange Rate Volatility on Exports: Some New Estimates." Economics Letters, October 1991, 37(2), pp. 173-77.

Bacchetta, Philippe and van Wincoop, Eric. "Does Exchange Rate Stability Increase Trade and Capital Flows?" NBER Working Paper 6704, August 1998.

Baum, Christopher F.; Caglayan, Mustafa and Ozkan, Neslihan. "Nonlinear Effects of Exchange Rate Volatility on the Volume of Bilateral Exports." Journal of Applied Econometrics, 2004, 19, pp. 1-23.

Bini-Smaghi, Lorenzo. "Exchange Rate Variability and Trade: Why is it so Difficult to Find any Empirical Relationship?" Applied Economics, 1991, 23(5), pp. 927-36.

Bollerslev, Timothy. "Generalized Autoregressive Conditional Heteroskedasticity." Journal of Econometrics, 1986, 31, pp. 307-27.

Brodsky, David A. "Fixed Versus Flexible Exchange Rates and the Measurement of Exchange Rate Instability." Journal of International Economics, 1984, 16, pp. 295-306.

Caporale, Tony and Doroodian, Khosrow. "Exchange Rate Variability and the Flow of International Trade." Economics Letters, 1994, 46, pp. 49-54.

Chowdhury, Abdur R. "Does Real Exchange Rate Volatility Depress Trade Flows? Evidence from Error-Correction Models." Review of Economics and Statistics, November 1993, 75(4), pp. 700-06.

Cote, Agathe. "Exchange Rate Volatility and Trade: A Survey" Bank of Canada Working Paper 94-5, May 1994.

Cushman, David O. "U.S. Bilateral Trade Flows and Exchange Risk During the Floating Period." Journal of International Economics, May 1988, 24(3-4), pp. 317-30.

De Grauwe, Paul. "Exchange Rate Variability and the Slowdown in Growth of International Trade." IMF Working Paper 87/38.

Ethier, Wilfred. "International Trade and the Forward Exchange Market." The American Economic Review, June 1973, 63(3), pp. 494-503. 
Fang, WenShwo; Lai, YiHao and Miller, Stephen M. "Does Exchange Rate Risk Affect Exports Asymmetrically? Asian Evidence." University of Connecticut Department of Economics Working Paper Series 2005-09, March 2005.

Gagnon, Joseph E. "Exchange Rate Variability and the Level of International Trade." Journal of International Economics, 1993, 34, pp. 269-87.

Hau, Harald. "Real Exchange Rate Volatility and Economic Openness: Theory and Evidence." Journal of Money Credit and Banking, August 2002, 34(3), pp. 611-30.

Hooper, Peter and Kohlhagen, Steven W. "The Effect of Exchange Rate Uncertainty on the Prices and Volume of International Trade." Journal of International Economics, 1978, 8, pp. 483-511.

Hummels, David. "Time as a Trade Barrier." July 2001, mimeo.

Kehoe, Timothy J. "The International Financial Crisis: Macroeconomic Linkages to Agriculture: Discussion." American Journal of Agricultural Economics, August 2000, 82(3), pp. 703-06.

Kenen, Peter B. and Rodrik, Dani. "Measuring and Analyzing the Effects of Short-Term Volatility in Real Exchange Rates." The Review of Economics and Statistics, May 1986, 68(2), pp. 311-15.

Klassen, Franc. "Why is it so Difficult to Find an Effect of Exchange Rate Risk on Trade?" August 1999, mimeo.

Koray, Faik and Lastrapes, William D. "Real Exchange Rate Volatility and U.S. Bilateral Trade: A VAR Approach." The Review of Economics and Statistics, November 1989, 71(4), pp. 708-12.

Langley, Suchada V.; Giugale, Marcelo; Meyers, William H. and Hallahan, Charles. "International Financial Volatility and Agricultural Commodity Trade: A Primer." American Journal of Agricultural Economics, August 2000, 82(3), pp. 695-700.

Maskus, Keith E. "Exchange Rate Risk and U.S. Trade: A Sectoral Analysis." Federal Reserve Bank of Kansas City Economic Review, March 1986, 71(3), pp. 16-28.

McKenzie, Michael D. "The Impact of Exchange Rate Volatility on International Trade Flows." Journal of Economic Surveys, February 1999, 13(1), pp. 71-106.

Mishkin, Frederic S. "Global Financial Instability: Framework, Events, Issues." The Journal of Economic Perspectives, Autumn 1999, 13(4), pp. 3-20.

Pick, Daniel H. "Exchange Rate Risk and U.S. Agricultural Trade Flows." American Journal of Agricultural Economics, August 1990, 72(3), pp. 694-700. 
Pozo, Susan. "Conditional Exchange-Rate Volatility and the Volume of International Trade: Evidence from the Early 1900s." The Review of Economics and Statistics, May 1992, 74(2), pp. 325-29.

Qian, Ying and Varangis, Panos. "Does Exchange Rate Volatility Hinder Export Growth? Additional Evidence." Empirical Economics, 1994, 19, pp.371-96.

Radelet, Steven; Sachs, Jeffrey D.; Cooper, Richard N. and Bosworth, Barry P. "The East Asian Financial Crisis: Diagnosis, Remedies, Prospects" Brookings Papers on Economic Activity, 1998(1), pp. 1-90.

Sercu, Piet. "Exchange Risk, Exposure, and the Option to Trade." Journal of International Money and Finance, 1992, 11, pp. 579-93.

Shane, Mathew D. and Liefert, William M. "The International Financial Crisis: Macroeconomic Linkages to Agriculture." American Journal of Agricultural Economics, August 2000, 82(3), pp. 682-87.

Thursby, Jerry G. and Thursby, Marie C. "Bilateral Trade Flows, the Linder Hypothesis, and Exchange Risk." The Review of Economics and Statistics, 1987, 69(3), pp. 488-95. 